\title{
Water resilience mapping of Chennai, India using analytical hierarchy process
}

\author{
R. Kaaviya ${ }^{*}(0)$ and V. Devadas
}

\begin{abstract}
Background: The urban water system is the worst hit in global climate change. Water resilience is the system's ability to retaliate and recover from various water-related disruptions. The present study aims to delineate the water resilience zones in Chennai city, Tamil Nadu, India, by effectively integrating the geographic information system, remote sensing, and analytical hierarchy process (AHP).

Methods: The methodology incorporated 15 vital factors. A multi-criteria decision analysis technique was adopted to assign a weight to each parameter using the AHP. A pairwise decision matrix was constructed, parameter's relative importance and the consistency ratio were established. Integration of all maps by weighted overlay analysis technique depicted water resilience intensities of five different classes.

Results: Very low, low and moderate water resilience areas accounted for more than three-fourth of the study area. Area Under Curve score (80.12\%) depicted the accuracy of the developed model. Sensitivity analysis determined the significance of the parameters in the delineation. The logical structural approach can be employed in other parts of India or elsewhere with modifications.

Conclusion: This study is novel in its approach by holistically analyzing water resilience by integrating disruptions related to flood, drought and the city's water infrastructure system's adequacy and efficiency. Researchers and planners can effectively use the study results to ensure resilience as a new perspective on effective water resource management and climate change mitigation. It becomes a decision aid mechanism identifying where the system is vulnerable to potential water-related risks for employing resilience measures.
\end{abstract}

Keywords: Water resilience, GIS, Remote sensing, Multi-criteria decision analysis, AHP

\section{Introduction}

Globally, water-related issues in urban areas have intensified the scientific community's concern (Marlow et al. 2013). Universally researchers and policymakers in urban development have recognized the importance of reinforcing resilience mechanisms in urban areas to cope with the disturbances caused by environmental changes (Basabe 2005; Cutter et al. 2010). The challenges experienced by the cities are complex and crucial. Growing population and climate change coerce the city's demand for

\footnotetext{
*Correspondence: kaaviya.r@ar.iitr.ac.in

Department of Architecture and Planning, Indian Institute of Technology Roorkee, Roorkee 247667, India
}

water, sea-level rise, and ability to handle urban floods/ storm surges. Resilience focuses not only on how the environment retaliates to disturbances associated with climatic changes but also on how well it can withstand and restructure with the growing demands and needs. Holling's term "resilience" was used in ecology to explain the system's ability to take up a disturbance and restructure and retaliate the changes but still perpetuate the required function, structure, and identity (Holling 1973). The term resilience in the setting of disaster risk reduction and management is defined community/system's capability to combat, absorb and recover from the impact of a threat in a timely and efficient manner. Water-related stress includes urban floods, water scarcity, groundwater overexploitation, stormwater runoff, and water pollution 
due to rapid urbanization and extreme weather (Marlow et al. 2013).

The inherent and adaptive capacities of a system's strength are related to the magnitude of disturbance the system is prone to. To assess the urban water system's resilience, there is a need to ascertain the level of stress it is exposed to (Walker and Salt 2012). Saunders and Becker (2015) further explored this idea with various earthquake prone case studies in New Zealand. They inferred that reducing risk/exposure results in enhancing resilience and sustainability. Bocchini et al. (2014) designed an integrated methodology quantitatively by analyzing the resilience level risk. In the present study, the study area is considered as a system. The resilience level in the system, i.e., the strength to recover after a water-related turmoil, corresponds to the level of stress intensities it is subjected to. This reiterates that the system's recovery capacity/resilience diminishes when susceptibility to water-related disruptions/risks/stress rises.

The monsoonal landscape is inherent to hydroclimatic extremes, such as droughts and floods. Although floods and droughts are generally regarded as opposites, they can co-occur, as droughts tend to be long and cumulative. In contrast, floods usually are short-lived and episodic. Climate change and haphazard development pose significant threats to flooding and water quality in urban areas (Miller and Hutchins 2017). In India, the prime reason for urban flooding is extreme and uncurbed surface runoff due to intense rainfall exceeding the drainage systems' capacity, referred to as pluvial flooding. Various environmental factors in the urban areas such as the urban sprawl, land use/land cover changes, increased impervious zones, irrational urban growth and flood management lead to pluvial flooding (Abebe et al. 2018; Miller and Hutchins 2017). These factors impact and further deteriorate the city's efficiency in combating urban flooding. Cities that are purely dependant on importing water from the surrounding areas are also affected by transmission and distribution losses. Researchers are analyzing the ways to meet the proliferating water demand while combating climatic changes. Increased demand for water is resulting in groundwater depletion. The drought aspects are complex and rely on varied interrelation with several hydrological parameters, such as precipitation, runoff, evaporation, infiltration and surface/groundwater storages (Sirdaş and Sen 2009; Mishra and Singh 2009). During scanty rainfall, the city finds it very difficult to manage with the prevailing saltwater. The issues get even worse during arid conditions. Effective water resource planning and management are inherent in diverse geospatial and remote sensing data.

The significant advantage of applying Geographic Information System (GIS) in water resource planning is its innate capacity in integrating and assessing numerous parameters over an extensive area (Wilson et al. 2000). Various applications of integrating GIS with multiple-criteria decision-making (MCDM) in urban planning, water resource management, and wetland management enhance the water resilience studies (Massam 1988; Gogate et al. 2017; Sudha Rani et al. 2015; Ouyang et al. 2011). These applications also enhance the spatial analysis, including the drain/ streamflow characteristics and distribution in the study area and the impact of varied landuse/land cover on water resources over an extensive period. Digital Elevation Models (DEM) and the hydrology tool in GIS can define the drainage basin boundaries by effectively delineating the watershed area and extracting the drain parameters that play a vital role in flood plain management and groundwater mapping.

Varied methods are being devised under multi-criteria decision analysis (MCDA), such as the analytical hierarchy process (AHP), goal programming and cost-benefit analysis (Pohekar and Ramachandran 2004). AHP techniques have been significantly applied for multi-criteria decision analysis, wherein a hierarchical framework is devised for decision-making (Saaty 2008). Integrated applications of GIS and MCDA aids researchers in assessing complex, voluminous data and its issues. The AHP developed by Saaty (1980) is an extensively used method in employing MCDA to optimize the decisionmaking process, including varied quantitative and qualitative parameters. He put forward a framework that implies arranging factors in a hierarchical manner from which the optimal solution is determined using pairwise comparison (Saaty 1980). Uncertainty in AHP is effectively remedied by utilising intermediate values on the 1-9 scale in combination with the verbal scale, which appears to create more accurate results than using fuzziness to modify the numbers for convenience and rather arbitrarily (Saaty 2006; Saaty and Tran 2007). Mosadeghi et al. (2015) suggested that the simpler MCDM approaches, such as AHP, should suffice if the planning goal is to identify priority zones for development as a focus point.

The application of AHP and GIS in an integrated manner has been successful in various studies, such as flood susceptibility mapping (Gogate et al. 2017; Mahmoud and Gan 2018; Kazakis et al. 2015; Msabi and Makonyo 2021; Desalegn and Mulu 2021; Sarmah et al. 2020; Ekmekcioğlu et al. 2021a); sustainable landuse planning (Paul et al. 2020; Zabihi et al. 2020); drought vulnerability mapping (Sivakumar et al. 2020; Hoque et al. 2020); groundwater potential zone mapping (Mukherjee and Singh 2020; Achu et al. 2020; Aykut 2021; Srivastava and Bhattacharya 2006). 
Mahmoud and Gan (2018) attempted to delineate varied levels of flood susceptible areas in Riyadh province, Saudi Arabia, by applying the AHP framework aiding in evolving weightage of each factor, such as flow accumulation, annual rainfall, slope, runoff, land use/cover, elevation, geology, soil type, distance from the drainage network, and drainage density. Kazakis et al. (2015) attempted to map the flood risk zones in the RhodopeEvros region of Greece by employing weighted overlay analysis based on the analytical hierarchy process. The highest influential factors identified were elevation, slope, and distance from the drainage network. Msabi and Makonyo (2021) and Desalegn and Mulu (2021) employed GIS and AHP to map the flood risk zones, which is an essential step towards flood mitigation planning. Sarmah et al. (2020) developed an urban flood hazard map for Guwahati, India, using AHP and GIS. The influence of seven urban flood causative variables (natural drainage, rainfall distribution, soil type, choking of natural drainage, landuse, population density and road network) were included in the study. A hierarchical approach based on thirteen flood vulnerability and hazard criteria is proposed to develop Istanbul's districtbased flood risk map using fuzzy AHP (Ekmekcioğlu et al. 2021a). Paul et al. (2020) integrated geospatial MCDA with AHP to assess the agricultural land suitability for irrigation with reclaimed water in California. This study led to a better understanding of sustainable reclaimed water use for crop irrigation at a regional level. Zabihi et al. (2020) integrated GIS with a Fuzzy-Analytic Hierarchy Process (F-AHP) to weigh the significance of physical, social, environmental, economic parameters for evaluating land suitability for eco-tourism sites in Babol, Iran. The results uttered that topography and distance from the stream, temperature and elevation, were crucial in determining the suitability index. Sivakumar et al. (2020), in their study, assessed the drought vulnerability in combination with remote sensing, GIS and AHP in Namakkal district, Tamil Nadu, India, using parameters, such as annual rainfall, land use/land cover (LULC), slope, soil type, Normalized Difference Vegetation Index (NDVI), Normalized Difference Water Index (NDWI) and population to alleviate drought-related stress. Hoque et al. (2020) employed a multi-criteria-based approach for mapping the spatial drought vulnerability using GIS and AHP in the North-western region of Bangladesh using annual precipitation, temperature LULC, soil moisture and texture, geomorphology, slope, elevation, groundwater level, drainage density, population density and other socio-economic factors. Achu et al. (2020) integrated remote sensing, GIS and AHP techniques in groundwater management. Various geo-environmental factors, such as lithology, geomorphology, land use/land cover, the density of lineaments and stream network, slope, and soil texture, are analyzed to delineate the potential groundwater zones in Manimala River Basin, Kerala State, India. Mukherjee and Singh (2020) and Aykut (2021) suggested the effectual groundwater management in varied geo-environmental context by combining GIS and AHP techniques. Srivastava and Bhattacharya (2006) coupled remote sensing, GIS and AHP in groundwater assessment in Bargarh district, Orissa, India. Various factors such as geomorphology, landuse, lithology, lineament, soil, drainage density, river gradient and slope maps are applied for groundwater resource management. In this present study, remote sensing, GIS and AHP were integrated to delineate zones subjected to water resilience of varied levels using various topographical, physiological, environmental, ecological and infrastructural factors, and the results could be used for optimal water resource management in the study area.

\section{Study area}

The Chennai city (with latitude between $12^{\circ} 50^{\prime} 4^{\prime \prime} \mathrm{N}$ and $13^{\circ} 17^{\prime} 24^{\prime \prime} \mathrm{N}$ and longitude between $79^{\circ} 58^{\prime} 53^{\prime \prime} \mathrm{E}$ and $80^{\circ} 20^{\prime} 12^{\prime \prime} \mathrm{E}$ ) lies on the Coromandal Coast of India (Fig. 1). It is a low-lying flat coastal plain with an average elevation of around $6.7 \mathrm{~m}$, witnessing a tropical climate. The city's municipal boundary had expanded from $174 \mathrm{~km}^{2}$ to $426 \mathrm{~km}^{2}$ by including the peri-urban areas around the core city, covering 200 wards with a population of 7,500,000 (2018).

The city's economy and the acute water utilizing industries and real estate activities have also been escalated, with an increased population from 500,000 to more than $6,000,000$ over the last century. Chennai, the 4th largest city in India, has been continuously facing periodic droughts and floods, struggling to meet the city's proliferating water demand. According to the World Resources Institute's aqueduct water risk atlas (World Resources Institute 2015), Chennai experiences extremely high baseline water stress. It measures the ratio of total water withdrawals to the annual available renewable surface water supplies. The city is susceptible to tropical disturbances and cyclones, urban floods, overflow of the major rivers/lakes/drains and clogging drainage network (Boyaj et al. 2018). The catastrophic floods (1943, 1978, 1985, 2002, 2005, 2015) were alarming because of the city's drainage system failure (Mujumdar et al. 2020; Bremner 2020). Despite copious flood occurrences, there is a significant gap in knowledge and method to evaluate the climate change impacts on urban flooding and the acute water crisis.

The city receives water from the reservoirs in Poondi, Cholavaram, Red Hills and Chemabarambakkam, well fields 


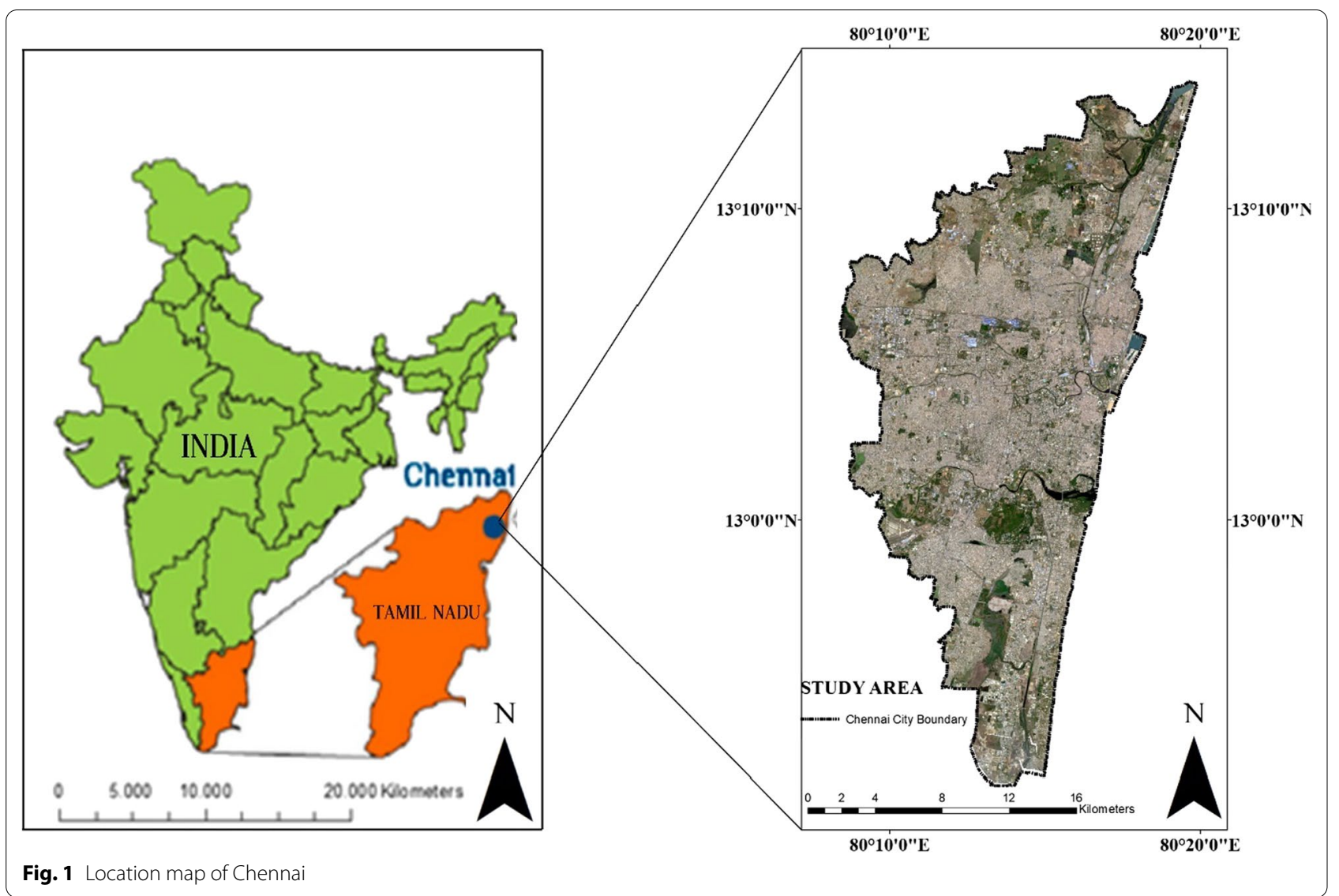

in Arani-Kosasthaliyar basin, Veeranam, Kandaleru-the distant reservoirs. The available groundwater in the wellfields is primarily utilized by the increasing water-intensive industries. After the severe drought in 2000, groundwater resources have been continuously over-exploited to meet the city's growing water demand (Ruet et al. 2007). The city's water supply depends mainly on the varying rainfall pattern, causing the city's reservoirs and lakes to dry mostly during the scanty rainfall period. As a result, the city has not been able to supply water to the growing population. Despite the flood devastation in 2015, the reservoirs were completely dry the following year, leaving the city in water crisis turmoil. The average monthly water storage levels of the Chembarambakkam and Redhills reservoirs drastically reduced between 2016 and 2017, from 49.6 MCM to 11.25 MCM and 43.6 MCM to 12.01 MCM, respectively (CMWSSB, n.d.). Kosasthaliyar, Cooum and Adyar are the major drains carrying the entire city's sewage, making them polluted, contaminated, and flowing into the sea. The city's natural drains, including the rivers and canals, are inefficient and insufficient in carrying the flood discharge. The drainage system has significant issues, such as a lack of required width to discharge floods caused by bridge construction, buildings within flood plains, sand bar formation at river mouths, clogging of drains due to indiscriminate solid waste dumping, inadequate design capacity, lack of connectivity of storm sewers with macro drainage, and encroachments (Corporation 2021; Narasimhan et al. 2016). The performance audit report of flood management and response in the city mentioned that the increased discharge of 353.96 $\mathrm{m}^{3} / \mathrm{s}$ of floodwaters in 2015 into the Buckingham Canal, which was meant to handle $254.85 \mathrm{~m}^{3} / \mathrm{s}$, resulted in the flooding of Velachery and surrounding regions (Government of Tamil Nadu 2017, p. 69). The disastrous floods that struck Chennai in 2015 claimed over 400 people and caused significant economic damage (Narasimhan et al. 2016). According to Aon Benfield's annual global climate and catastrophe report, India's economy incurred a 200 billion INR (USD 3 billion) loss as a result of the torrential rainfall and flooding in Chennai in November and early December of 2015 (Aon Benfield 2015, p. 3,7), and the seventh-most fatal global disaster in 2015 (Aon Benfield 2016, p. 6).

Every other year, the city has experienced recurring droughts and floods. The drastic climate change resulted in a severe setback during heavy rainfall, leading to floods, storm surges, and associated socio-economic, economic, and environmental problems. The recovery from this ill effect takes a minimum of 2 years to come back to the 
original situation. By that end, drought occurs, causing severe water scarcity even for domestic purposes. This creates socio-economic schisms in the system that paved the way for distress among the people and unhealthy situations in the system's function. Chennai Metropolitan Water Supply and Sewerage Board (CMWSSB), with the assistance of the United Nations Development Programme (UNDP), has undertaken various studies on water availability stated that the inconsistency of rainfall patterns over the years, combined with an increase in dry periods, has depleted groundwater levels in turn affecting the reservoir storage levels (UNDP 1987). Water supply from the city's desalination plants and the distant supply from the Veeranam reservoir hardly meets a quarter of the total demand. During the summer season, the direct water supply through water pipes is almost shut down, increasing the groundwater extraction rate leading to its depletion and seawater's intrusion (Rajaveni et al. 2016). Even with the advent of urban development and management measures, the city continues to deteriorate, with a minimum litre per capita per day (LPCD) of the water supply of just 108 LPCD (Roumeau et al. 2015), far less than the WHO minimum benchmark of 150 LPCD. Chennai city lacks a holistic approach to analyzing the extremities of drought, floods, and other water-related infrastructure system inefficacies.

\section{Materials and methods}

The droughts and flood events were remarkably increasing in magnitude and frequency in Chennai city. The flood events caused extended damages to infrastructures. On the other hand, significant drought increases the water stress in the study area. The research paper is novel in its approach by holistically analyzing water resilience by integrating the disruptions related to flood, drought and the city's water infrastructure system's adequacy and efficiency. A preliminary survey was conducted in which local people and public representatives (city development authorities) were consulted to understand the city's water-related threats. The significant problems identified from the discussions are the city's haphazard development, depletion and encroachments of water bodies and vegetation cover, including the wetlands, thereby increasing the surface runoff and groundwater exploitation. Furthermore, we met officials and reviewed reports from various departments of Greater Chennai Corporation, and subsequently, the need has been established to delineate water resilience zones in the study area. The technical expertise of 13 experts was used in this study. As a member of one of the four stakeholders (university, corporation/metropolitan administration, disaster management centre, water supply and sewerage board), each expert had the expertise for a minimum of 5 years. The expert's affiliation with works linked to the city's water management and disaster management for at least 5 years was required to understand the comprehensive dimension of urban water resilience.

Additional file 2: Table S1 depicts the expert's profile who participated in the survey questionnaire. Purposive sampling was used to identify experts, and each expert's experience was carefully examined. It aided in gaining a comprehensive understanding of the subject under discussion, allowing their decisions to reflect the dynamics of water resilience (Ekmekcioğlu et al. 2021b; Hasan et al. 2018). The comprehensiveness of the parameters considered is checked in the in-person survey. They were asked to review the inclusiveness of the list in delineating water resilience zones. Researchers working on related topics have used a similar approach (Sarmah et al. 2020; Jain and Ramsankaran 2019).

Figure 2 explains the methodology adopted in the study. This present study integrates remote sensing, GIS, and AHP to determine the varied water resilience zones in Chennai city. Once the fifteen factors had been validated, the experts were asked to rank them using a questionnaire based on the AHP. The AHP developed by (Saaty 1980) is a relevant tool in categorizing and assessing multiple parameters by ascertaining certain weights to each parameter in a hierarchical framework. The steps involved in MCDA with the AHP framework is discussed in the following paragraphs. The first step is the pairwise comparison of the selected parameters. The AHP technique is applied in the study, where the pairwise comparison matrix's evaluation criteria were computed based on the expert's opinions through a survey questionnaire to assess the relative importance of the parameter. Saaty (1980) advocated using a numerical scale (Table 1) to score the parameter's significance in the pairwise comparison matrix. The complex inter-relation has been fragmented into a hierarchical structure. Each criterion/alternative $i$ is compared to each criterion or alternative $j$. Pairwise comparison is made to construct the decision matrix, where the comparison criteria are used to complete the upper triangular matrix, while the lower triangular matrix is its reciprocals. The decision pairwise comparison matrix is represented as below:

$$
A=\left[\begin{array}{cccc}
1 & a_{12} & \ldots & a_{1 n} \\
\frac{1}{a_{12}} & 1 & a_{23} & a_{2 n} \\
\ldots & \frac{1}{a_{23}} & \ldots & \ldots \\
\frac{1}{a_{1 n}} & \frac{1}{a_{2 n}} & \ldots & 1
\end{array}\right] .
$$

Table 2 depicts the pairwise comparison matrix of the present study. The next step is to synthesize the pairwise comparison matrix into a priority/normalized matrix. Then, each element in the column is divided by its 


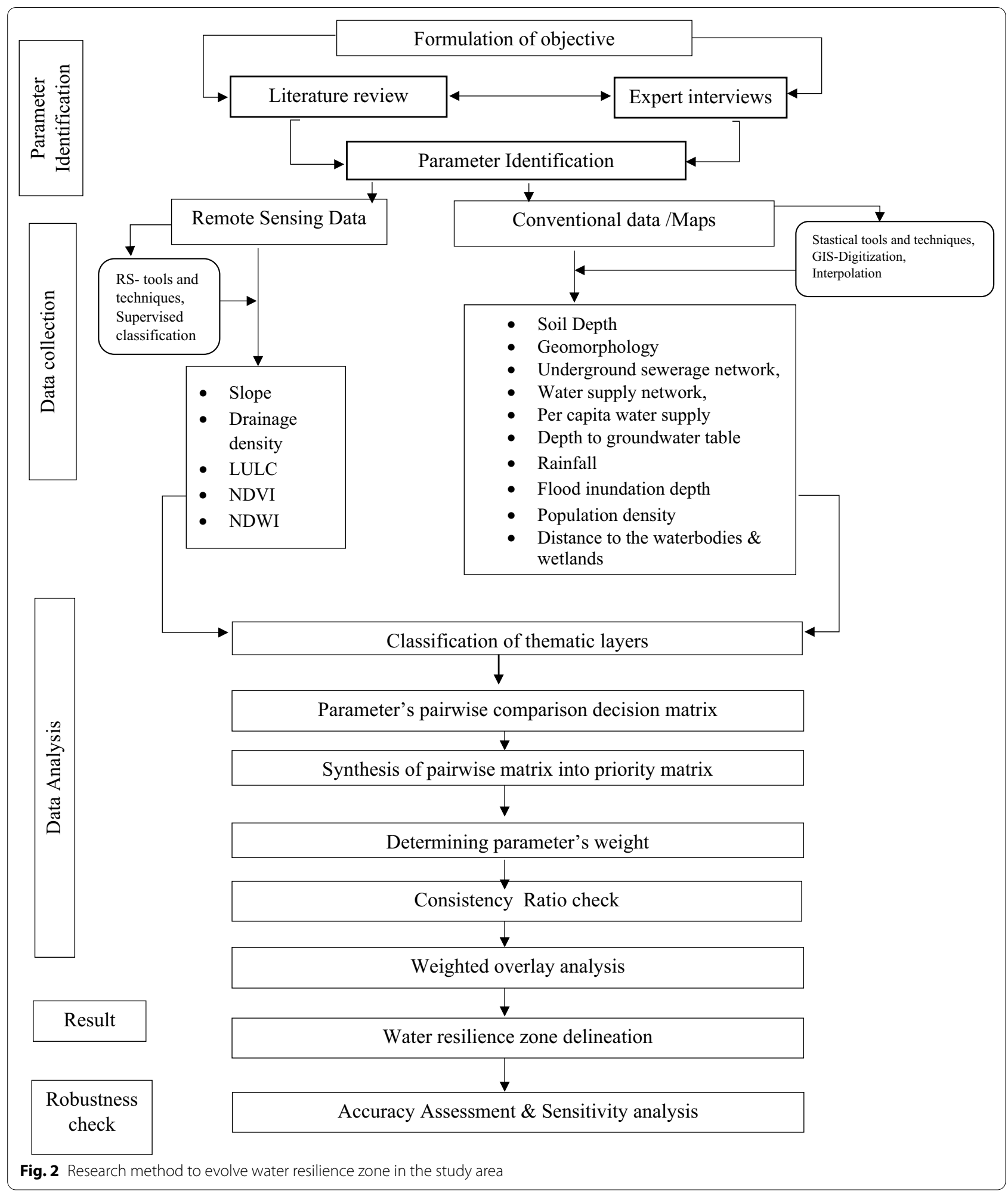

respective column's sum to yield the normalized score in framing the normalized matrix $\left(X_{i j}\right)$ :

$$
X_{i j}=a_{i j} / \sum_{i=1}^{n} a_{i j}[i, j=1,2,3, \ldots n] .
$$


Table 1 Saaty's scale of importance (Saaty 1980)

\begin{tabular}{ll}
\hline Intensity of importance & Definition \\
\hline 1 & Equal importance \\
2 & Equal to moderate importance \\
3 & Moderate importance \\
4 & Moderate to strong importance \\
5 & Strong importance \\
6 & Strong to very strong importance \\
7 & Very strong importance \\
8 & Very strong to extremely strong importance \\
9 & Extremely strong importance \\
\hline
\end{tabular}

The weightage of each parameter is calculated using the below equation 2 . It is the quotient between the sum of all the parameter's respective scores in each row and the number of parameters used:

$$
W_{i j}=\sum_{j=1}^{n} X_{i j} / n[i, j=1,2,3, \ldots n] \text { and } n=\text { number of parameters used. }
$$

a given basin to the entire basin area. The raster is then categorized into five varying scales. Geomorphology and soil depth data are obtained from the Geological Survey of India and India Water Resources Information System, respectively. Average annual rainfall (1965-2020) data are collected from the India Water Resources Information System with nine- gauge stations, namely, Poondi, Cholavaram, Redhills, Thamaraipakkam, Chembarambakkam, Korattur, Veeranam, Nungambakkam and Meenambakkam. The values are then interpolated using the ArcGIS tool to map the study area's annual mean rainfall. Depth to the water table below ground level is collected from IWRIS, which includes data from 20 stations (2001-2020), encompassing, Alwarpet, Tondiarpet, Saidapet, Taramani, Villivakkam, Chepauk, Perambur, Santhome, Velachery, Mandaveli, Vallalar Nagar, Vepery, Thousand lights, Kodambakkam, Adyar, Guindy, Besant Nagar, Aminjikarai, Vyasarpadi and Thyagaraya Nagar. The annual mean values are then interpolated,
The next step is to check the pairwise comparison's consistency, which is advantageous for assessing whether the judgments are reliable and consistent by computing the consistency ratio. It is a quotient between the CI and RI as follows:

$$
\mathrm{CR}=\mathrm{CI} / \mathrm{RI}(\mathrm{CR}-\text { Consistency Ratio; CI - Consistency Index; RI - Random Index }) \text {. }
$$

where

$$
\mathrm{CI}=\frac{\lambda_{\max }-n}{n-1}[n=\text { number of parameters used }] .
$$

First, the pairwise matrix is multiplied by the vector weights resulting in the weighted sum vector. It is then divided by the criterion weight to generate the consistency vector, which calculates the $\lambda_{\text {max }}$ principal eigenvector value. The Random Index varies with the number of parameters used (Saaty 1980).

The CR value should be less than 0.1 for reliable and consistent judgments in the pairwise comparison in the AHP process.

The Shuttle Radar Topography Mission (SRTM) data helped to obtain the data on the topographical factors. The DEM and the slope maps are extracted using SRTM data with $16 \mathrm{~m}$ spatial resolution using ArcGIS 10.1 software. Furthermore, with the help of hydrology tools in ArcGIS, the study area's drainage density is generated. Drainage density is the measure of total stream length in employing the Kriging spatial interpolation tool in ArcGIS to classify groundwater table below ground level in the study area. LANDSAT-8 OLI is downloaded from the USGS Earth Explorer with 30 m resolution to generate the land use/land cover classification using maximum

$$
\text { cloul }
$$
Difference Vegetation Index (NDVI) is calculated using the difference in the intensities of reflected light in the Near-Infrared (NIR) and red (R) range and divided by these intensities' sum. The Normalized Difference Water Index (NDWI) is derived from the Near-Infrared (NIR) and Green (G) channels using the Remote Sensing Technique. The ward-level data for the flood inundation depth above ground level was collected from the Tamil Nadu State Disaster Management Authority for 2005 and 2015. Field survey data for 2020 is also used to calculate the maximum inundation depth in every ward in the study area. The ward-level data of water supply infrastructure and underground sewerage network are obtained from the Chennai Metropolitan Water Supply \& Sewerage Board project reports. Data concerning the population 
Table 2 Pairwise comparison matrix

\begin{tabular}{|c|c|c|c|c|c|c|c|c|c|c|c|c|c|c|c|}
\hline Criteria & SD & GM & DD & DW & FID & LULC & USN & WSN & $\mathrm{RF}$ & PWS & DSW & PD & SP & NDVI & NDWI \\
\hline SD & 1 & 2 & 2 & 2 & 2 & 3 & 3 & 3 & 5 & 5 & 7 & 7 & 8 & 8 & 9 \\
\hline GM & 0.5 & 1 & 2 & 2 & 2 & 3 & 3 & 3 & 5 & 5 & 7 & 7 & 8 & 8 & 8 \\
\hline DD & 0.50 & 0.50 & 1 & 2 & 2 & 2 & 3 & 3 & 4 & 5 & 6 & 6 & 7 & 7 & 8 \\
\hline DW & 0.50 & 0.50 & 0.50 & 1 & 2 & 2 & 2 & 3 & 4 & 5 & 5 & 6 & 6 & 7 & 7 \\
\hline FID & 0.50 & 0.50 & 0.50 & 0.50 & 1 & 2 & 2 & 3 & 4 & 4 & 5 & 5 & 6 & 6 & 6 \\
\hline LULC & 0.33 & 0.33 & 0.20 & 0.50 & 0.50 & 1 & 2 & 2 & 3 & 4 & 4 & 5 & 5 & 6 & 6 \\
\hline USN & 0.33 & 0.33 & 0.33 & 0.50 & 0.50 & 0.50 & 1 & 2 & 3 & 4 & 4 & 5 & 5 & 6 & 6 \\
\hline WSN & 0.33 & 0.33 & 0.33 & 0.33 & 0.33 & 0.50 & 0.50 & 1 & 2 & 3 & 3 & 4 & 5 & 6 & 6 \\
\hline $\mathrm{RF}$ & 0.20 & 0.20 & 0.25 & 0.25 & 0.25 & 0.33 & 0.33 & 0.50 & 1 & 2 & 3 & 4 & 5 & 5 & 5 \\
\hline PWS & 0.20 & 0.20 & 0.20 & 0.20 & 0.25 & 0.25 & 0.25 & 0.33 & 0.50 & 1 & 2 & 3 & 4 & 5 & 5 \\
\hline DSW & 0.14 & 0.14 & 0.17 & 0.20 & 0.20 & 0.25 & 0.25 & 0.33 & 0.33 & 0.50 & 1 & 2 & 3 & 4 & 4 \\
\hline PD & 0.14 & 0.14 & 0.17 & 0.17 & 0.20 & 0.20 & 0.20 & 0.25 & 0.25 & 0.33 & 0.50 & 1 & 3 & 3 & 4 \\
\hline SP & 0.13 & 0.13 & 0.14 & 0.17 & 0.17 & 0.20 & 0.20 & 0.20 & 0.20 & 0.25 & 0.33 & 0.33 & 1 & 2 & 3 \\
\hline NDVI & 0.13 & 0.13 & 0.14 & 0.14 & 0.17 & 0.17 & 0.17 & 0.17 & 0.20 & 0.20 & 0.25 & 0.33 & 0.50 & 1 & 2 \\
\hline NDWI & 0.11 & 0.13 & 0.13 & 0.14 & 0.17 & 0.17 & 0.17 & 0.17 & 0.20 & 0.20 & 0.25 & 0.25 & 0.33 & 0.50 & 1 \\
\hline
\end{tabular}

Refer Sect. Factors used in water resilience zone delineation for the acronyms

and water supply in each ward is obtained from Chennai Smart City Limited (Table 3 ). The population density is then measured by dividing each ward's total population by the total ward area. The ward-level water supply (in litres per capita per day) is the quotient between the total water supplied per day to each ward and the ward's total population.

Each factor was categorized into varied classes, wherein their water resilience capability levels and corresponding scores are tabulated in Table 3. According to Saaty's 1-9 scale, the sub-criteria were scored, where 1 and 9 show the lowest and highest water resilience level, it is subjected. The lower the score, the lower is the water resilience. This specifies that with higher water-related disruptions/risk/susceptibility, the system's recovery capacity/resilience is relatively low. By employing AHP, the parameter's weights and scores were determined for the GIS-MCDA model. The parameters of varied resolution are then resampled using ArcGIS to $30 \mathrm{~m}$ resolution. Using the weighted overlay analysis, water resilience zones are generated by integrating their significances to the respective parameters derived from the AHP process. After assigning the derived weights from AHP and scores to each subclass, the water resilience zones can be determined by integrating all the thematic layers of the parameters using the weighted overlay technique, one of the spatial analyst tools in ArcGIS employing the below equation:

$$
\mathrm{WRZ}=\sum_{i=1}^{n}\left(w_{i} * s_{i}\right)
$$

where WRZ is the Water Resilience Zone, the weight of each thematic layer is denoted by $w_{i}$ and the subclasses score of the respective thematic layer is denoted by $s_{i}$.

After the weighted overlay analysis, the extracted map of $30 \mathrm{~m}$ resolution is then categorized into very low, low, moderate, high and very high classes to determine the study area's water resilience zone.

Then the robustness of the factor's weight is determined using the sensitivity analysis. It explores how the water resilience zone's area encompassing varied levels is changed with a slight variation in the input parameters to identify the study's critical determining factors:

$$
P_{i}^{j}=\left[\left(A_{i}^{j}-A_{n}^{j}\right) / A_{n}^{j}\right] \times 100 .
$$

Here, $i$ denotes the factor number, and $j$ represents the water resilience zone (low/moderate/high). Besides, $P_{i}^{j}$ is the percentage area deviation in the $j$ th class of WRZ area due to the exclusion of $i$ th criteria, whereas $A_{i}^{j}$ is the $j$ th class of WRZ area due to removal of the $i$ th criteria, and $A_{n}^{j}$ is the $j$ th class of WRZ area using all the parameters. Furthermore, the average deviation is also calculated to determine the maximum variation by excluding that parameter. It will clearly depict the significance of that particular parameter in the analysis of the water resilience zone.

The average deviation in the area change when the parameters are removed is a quotient between the sum of $P_{\mathrm{vl}}, P_{\mathrm{l}}, P_{\mathrm{m}}, P_{\mathrm{h}}, P_{\mathrm{vh}}$ and ' $n$ '. $P_{\mathrm{vl}}, P_{\mathrm{l}}, P_{\mathrm{m}}, P_{\mathrm{h}}, P_{\mathrm{vh}}$ denotes the area deviation (\%) in the very low, low, moderate, and high and very high-water resilience zone, 
Table 3 Water resilience determining parameters and their sub-classes with area and weights

\begin{tabular}{|c|c|c|c|c|c|c|c|c|}
\hline S. No. & Parameters & Class & Water resilience & Score & Area $\left(\mathrm{km}^{2}\right)$ & Percentage (\%) & Source & Weight \\
\hline \multirow[t]{2}{*}{1} & \multirow[t]{2}{*}{ Soil depth (cm) } & $\begin{array}{l}\text { Extremely shallow } \\
(<10)\end{array}$ & Very low & 1 & 252.119 & 59.18 & \multirow[t]{2}{*}{$\begin{array}{l}\text { India Water Resources } \\
\text { Information System }\end{array}$} & \multirow[t]{2}{*}{0.167} \\
\hline & & $\begin{array}{l}\text { Moderately shallow } \\
(>50)\end{array}$ & Moderate & 5 & 173.881 & 40.82 & & \\
\hline \multirow[t]{4}{*}{2} & \multirow[t]{4}{*}{ Geomorphology } & Coastal plain & Very low & 1 & 119.28 & 28.00 & \multirow{4}{*}{$\begin{array}{l}\text { Geological Survey of } \\
\text { India }\end{array}$} & \multirow[t]{4}{*}{0.149} \\
\hline & & Deltaic plain & High & 7 & 225.78 & 53.00 & & \\
\hline & & Flood plain & Very low & 1 & 12.78 & 3.00 & & \\
\hline & & $\begin{array}{l}\text { Pediment pediplain } \\
\text { complex }\end{array}$ & Moderate & 5 & 68.16 & 16.00 & & \\
\hline \multirow[t]{5}{*}{3} & \multirow{5}{*}{$\begin{array}{l}\text { Drainage density }(\mathrm{km} / \\
\left.\mathrm{km}^{2}\right)\end{array}$} & $<0.00236$ & Very high & 9 & 99.388 & 23.33 & \multirow{5}{*}{$\begin{array}{l}\text { Based on DEM from } \\
\text { SRTM }\end{array}$} & \multirow[t]{5}{*}{0.125} \\
\hline & & $0.00236-0.0072$ & High & 7 & 127.863 & 30.01 & & \\
\hline & & $0.0072-0.0127$ & Moderate & 5 & 110.933 & 26.04 & & \\
\hline & & $0.0127-0.0195$ & Low & 3 & 72.059 & 16.92 & & \\
\hline & & $0.0195-0.043$ & Very low & 1 & 15.757 & 3.70 & & \\
\hline \multirow[t]{5}{*}{4} & \multirow{5}{*}{$\begin{array}{l}\text { Depth to water table } \\
\text { (metres below ground } \\
\text { level) }\end{array}$} & $4.45-6.03$ & Very high & 9 & 44.625 & 10.48 & \multirow{5}{*}{$\begin{array}{l}\text { India Water Resources } \\
\text { Information System }\end{array}$} & \multirow[t]{5}{*}{0.108} \\
\hline & & $6.04-6.92$ & High & 7 & 76.715 & 18.01 & & \\
\hline & & $6.93-7.73$ & Moderate & 5 & 92.535 & 21.72 & & \\
\hline & & $7.73-8.59$ & Low & 3 & 162.091 & 38.05 & & \\
\hline & & $8.60-10.03$ & Very low & 1 & 50.035 & 11.75 & & \\
\hline \multirow[t]{5}{*}{5} & \multirow{5}{*}{$\begin{array}{l}\text { Flood inundation } \\
\text { depth (feet above } \\
\text { ground level) }\end{array}$} & $<2$ & Very high & 9 & 32.525 & 7.64 & \multirow{5}{*}{$\begin{array}{l}\text { Tamil Nadu State } \\
\text { Disaster Management } \\
\text { Authority }\end{array}$} & \multirow[t]{5}{*}{0.094} \\
\hline & & $2-3$ & High & 7 & 125.521 & 29.47 & & \\
\hline & & $3-4$ & Moderate & 5 & 130.275 & 30.58 & & \\
\hline & & $4-5$ & Low & 3 & 102.470 & 24.05 & & \\
\hline & & $>5$ & Very low & 1 & 35.210 & 8.27 & & \\
\hline \multirow[t]{4}{*}{6} & Land use/Land cover & Settlements & Very low & 1 & 330.826 & 77.66 & Calculated from & 0.073 \\
\hline & & Vegetation & Very high & 9 & 42.939 & 10.08 & LANDSAT-8 OLI, USGS & \\
\hline & & Waterbodies & Very low & 1 & 31.751 & 7.45 & & \\
\hline & & Scrubs \& Bare soil & Moderate & 7 & 20.483 & 4.81 & & \\
\hline 7 & Rainfall (mm) & $<1092$ & Very low & 1 & 223.545 & 52.48 & India Water Resources & 0.068 \\
\hline & & $1092-1168$ & Moderate & 5 & 72.061 & 16.92 & Information System & \\
\hline & & $1168-1264$ & High & 7 & 35.872 & 8.42 & & \\
\hline & & $1264-1323$ & Low & 3 & 32.241 & 7.57 & & \\
\hline & & $1323-1417$ & Very low & 1 & 62.280 & 14.62 & & \\
\hline 8 & Underground sewer- & $<20$ & Very low & 1 & 47.712 & 11.20 & Based on Chennai & 0.055 \\
\hline & age network coverage & $20-40$ & Low & 3 & 59.555 & 13.98 & Metro Water Supply & \\
\hline & & $40-60$ & Moderate & 5 & 112.847 & 26.49 & reports and Survey & \\
\hline & & $60-80$ & High & 7 & 57.766 & 13.56 & & \\
\hline & & $>80$ & Very high & 9 & 148.120 & 34.77 & & \\
\hline 9 & Water supply network & $<40$ & Very low & 1 & 29.755 & 6.98 & Based on Chennai & 0.042 \\
\hline & coverage (\%) & $40-60$ & Low & 3 & 146.578 & 34.41 & Metro Water Supply & \\
\hline & & $60-80$ & Moderate & 5 & 79.148 & 18.58 & reports and Survey & \\
\hline & & $>80$ & Very high & 9 & 170.518 & 40.03 & & \\
\hline 10 & Per capita water sup- & $<40$ & Very low & 1 & 101.404 & 23.80 & Chennai Smart City & 0.034 \\
\hline & ply (lpcd) & $40-60$ & Very low & 1 & 123.353 & 28.96 & Limited & \\
\hline & & $60-90$ & Low & 3 & 81.950 & 19.24 & & \\
\hline & & $90-120$ & Moderate & 5 & 40.700 & 9.55 & & \\
\hline & & $>120$ & High & 7 & 78.592 & 18.45 & & \\
\hline 11 & Distance from the & $<500$ & Very low & 1 & 141.540 & 33.23 & & 0.025 \\
\hline & water bodies and & $500-1000$ & Moderate & 5 & 208.210 & 48.88 & & \\
\hline & & $>1000$ & High & 7 & 76.250 & 17.90 & & \\
\hline
\end{tabular}


Table 3 (continued)

\begin{tabular}{|c|c|c|c|c|c|c|c|c|}
\hline S. No. & Parameters & Class & Water resilience & Score & Area $\left(\mathrm{km}^{2}\right)$ & Percentage (\%) & Source & Weight \\
\hline \multirow[t]{5}{*}{12} & \multirow{5}{*}{$\begin{array}{l}\text { Population density } \\
\text { (persons } / \mathrm{km}^{2} \text { ) }\end{array}$} & $1000-5000$ & Very high & 9 & 120.563 & 28.30 & \multirow{5}{*}{$\begin{array}{l}\text { Chennai Smart City } \\
\text { Limited }\end{array}$} & \multirow[t]{5}{*}{0.021} \\
\hline & & $5000-10,000$ & High & 7 & 65.425 & 15.36 & & \\
\hline & & $10,000-20,000$ & Moderate & 5 & 81.009 & 19.02 & & \\
\hline & & $20,000-50,000$ & Low & 3 & 128.203 & 30.09 & & \\
\hline & & $>50,000$ & Very low & 1 & 30.801 & 7.23 & & \\
\hline \multirow[t]{5}{*}{13} & \multirow[t]{5}{*}{ Slope (\%) } & $0-3.35$ & Very low & 1 & 152.04 & 35.69 & \multirow{5}{*}{$\begin{array}{l}\text { Based on DEM from } \\
\text { SRTM }\end{array}$} & \multirow[t]{5}{*}{0.0155} \\
\hline & & $3.35-5.96$ & Very low & 1 & 160.69 & 37.72 & & \\
\hline & & $5.96-10.06$ & Low & 3 & 91.83 & 21.56 & & \\
\hline & & $10.06-20.12$ & Moderate & 5 & 19.86 & 4.66 & & \\
\hline & & $20.12-95.04$ & High & 7 & 1.57 & 0.37 & & \\
\hline \multirow[t]{5}{*}{14} & \multirow[t]{5}{*}{ NDVI } & $(-0.87)$ to $(-0.63)$ & Very low & 1 & 122.42 & 28.74 & \multirow{5}{*}{$\begin{array}{l}\text { Calculated from } \\
\text { LANDSAT-8 OLI, USGS } \\
\text { Earth Explorer }\end{array}$} & \multirow[t]{5}{*}{0.012} \\
\hline & & $(-0.63)$ to $(-0.59)$ & Very low & 1 & 114.83 & 26.96 & & \\
\hline & & $(-0.59)$ to $(-0.54)$ & Low & 3 & 125.54 & 29.47 & & \\
\hline & & $(-0.54)$ to $(-0.47)$ & Moderate & 5 & 52.38 & 12.30 & & \\
\hline & & $(-0.47)$ to $(-0.43)$ & High & 7 & 10.83 & 2.54 & & \\
\hline \multirow[t]{5}{*}{15} & \multirow[t]{5}{*}{ NDWI } & $0.47-0.55$ & Very low & 1 & 65.45 & 15.36 & \multirow{5}{*}{$\begin{array}{l}\text { Calculated from } \\
\text { LANDSAT-8 OLI, USGS } \\
\text { Earth Explorer }\end{array}$} & \multirow[t]{5}{*}{0.01} \\
\hline & & $0.55-0.59$ & Low & 3 & 106.77 & 25.06 & & \\
\hline & & $0.59-0.62$ & Moderate & 5 & 142.80 & 33.52 & & \\
\hline & & $0.62-0.65$ & High & 7 & 95.01 & 22.30 & & \\
\hline & & $0.65-0.86$ & Very high & 9 & 15.98 & 3.75 & & \\
\hline
\end{tabular}

respectively. ' $n$ ' is the total number of determined water resilience zone levels.

\section{Results and discussion}

Factors used in water resilience zone delineation Soil depth (SD)

Soil depth, an important parameter, denotes the infiltration capacity, which is vital both during flood and drought. The deeper soil retains water significantly compared to the shallower soils, where the infiltration capacity is fragile and degraded (Kourgialas et al. 2018). More than half of the city area (59\%) falls under the extremely shallow category having a depth of less than $10 \mathrm{~cm}$ (Fig. 3; Table 3 ). These have less infiltration capacity accounting for drought and urban flood and are subjected to very low water resilience.

\section{Geomorphology (GM)}

Geomorphology is an essential factor in floodplain management, stormwater routing, and efficient water resources management. The coastal plain and flood plain are prone to floods/storm surges and extremely poor infiltration capacity (Periyasamy et al. 2018). Deltaic plain constitutes more than half of the study area (53\%), susceptible to periodic flooding due to its moderate infiltration rate. The coastal plain includes about one-fourth of the study area (28\%) prone to storm surges because of this zone's silty clayey soil deposits. Pediment pediplain constitutes about one-sixth of the city area (16\%) with much-reduced infiltration capacity and acts as a runoff zone (Fig. 3). Flood plain comprises $3 \%$ of the study area-seasonal flood zone because of gravel, sand, and silt deposits.

\section{Drainage density (DD)}

Surface runoff is more significant in zones with higher drainage density. Higher drainage density zones are associated with sparse to nil vegetation, impermeable subsurface and high runoff potential basin area (Kumar et al. 2007; Srivastava and Bhattacharya 2006). Very high and high drainage density area accounts for about one-fifth of the study area $(21 \%)$ subjected to very low and low water resilience, respectively (Table 3; Fig. 3).

\section{Depth to the water table (DW)}

It is the depth of the water table below the ground level. An increase in the depth to the water table below ground level is explicitly related to the drought scenario, including the decline in precipitation and subsurface infiltration (Kourgialas et al. 2018). The depth to the water table, 


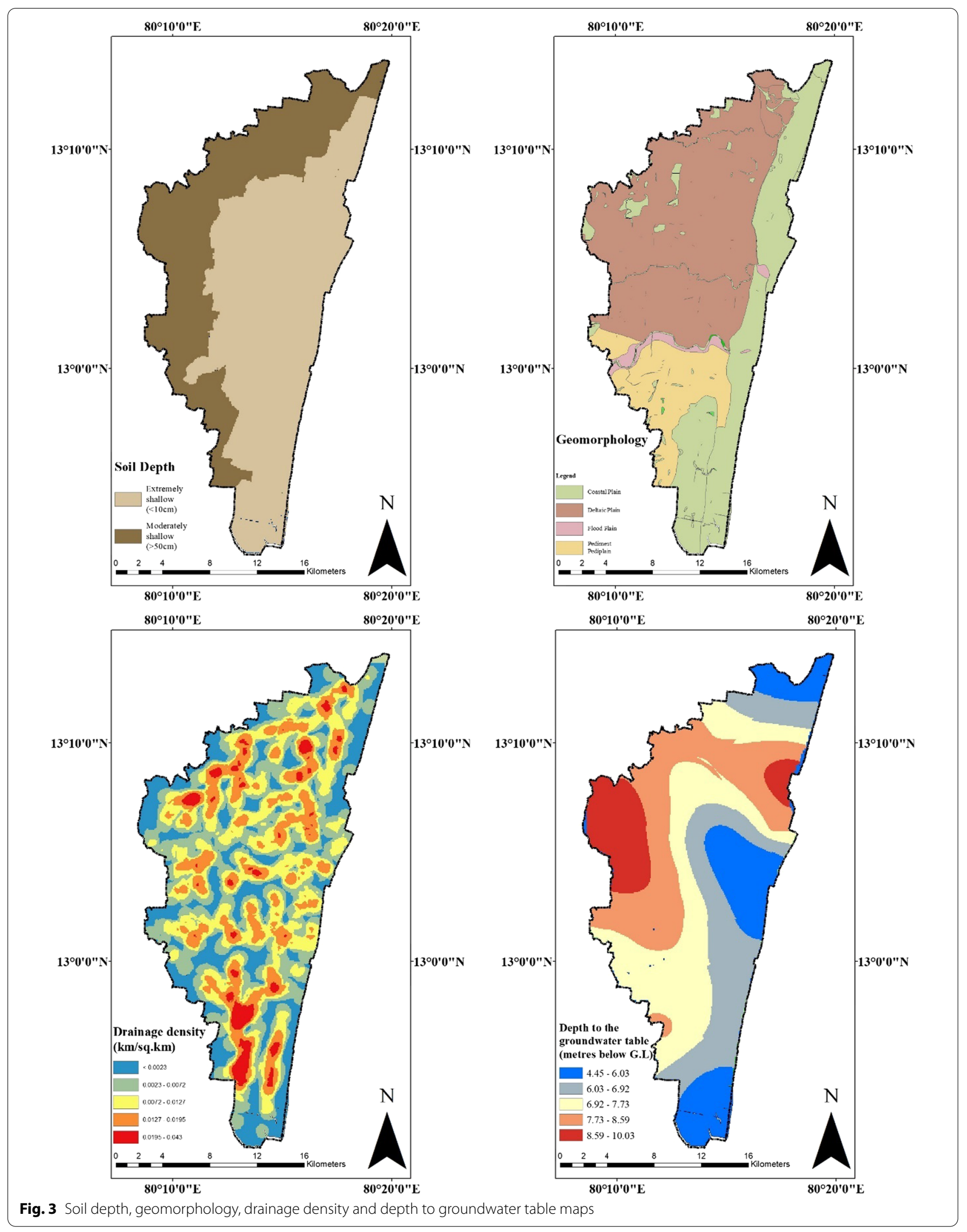


ranging from $7.74 \mathrm{~m}$ to $10.03 \mathrm{~m}$ below ground level, accounts for nearly half of the study area (49.79\%), subject to relatively low water resilience (Table 3; Fig. 3).

\section{Flood inundation depth (FID)}

Flood inundation depth measures water level depth above the ground level during flood/storm surges. Inundation is the most apparent method for representing storm surge and heavy rainfall driven coastal flooding. Increase in the depth of inundation, the water resilience level is prone to be extremely low (Table 3 ). The inundation depth ranging between $4^{\prime}$ and $5^{\prime}$ above the ground level is observed in about one-fourth of the study area (24.05\%), subjected to low water resilience (Fig. 4).

\section{Land use/land cover (LULC)}

Urbanization can create more surface runoff and maximum stress in groundwater than bare soil and vegetation cover (Kourgialas and Karatzas 2011). In this study, built-up areas are assigned with a relatively low water resilience level, covering nearly three-fourth of the total study area (78\%) (Fig. 4). The increase in built-up area corresponds to the impervious surface, which has a relatively higher runoff volume. The vegetation and bare soil land cover are prone to relatively higher water resilience because of the infiltration capacity.

\section{Rainfall (RF)}

Annual mean rainfall data plays a vital role in delineating water resilience as it determines both the scanty and heavy rainfall zones. It improves groundwater recharging and surface water. In contrast, more than the average rainfall, downpour brings flood/storm surges as water flow is obstructed due to various hindrances. Rainfall data from 1965 to 2020 were analyzed to prepare the rainfall isohyet map (Fig. 4) with ArcView GIS Software's help. The normal rainfall in the study area ranges from 1092 to $1264 \mathrm{~mm}$. The isohyet map shows about one-fourth of the study area $(22.4 \%)$ received heavy to very heavy rain. More than half of the study area (52\%) received scanty rainfall less than $1092 \mathrm{~mm}$. Both are subjected to relatively low water resilience.

\section{Underground sewerage network (USN)}

Underground sewerage network coverage denotes the level to which wastewater management infrastructure is viable to each ward's individual properties through a separate, underground sewerage system (Ministry of Urban Development, n.d.). Areas with relatively less sewerage network coverage are subjected to low water resilience because of the reduced sewerage water collected for treatment, thereby curtailing secondary water supply for reuse (Fig. 4). It also increases surface runoff in the monsoon. Very low and low sewerage network coverage is observed in $11.20 \%$ and $13.98 \%$ of the study area, respectively (Table 3 ).

\section{Water supply network (WSN)}

It is an infrastructural provision determining the coverage to which the households in each ward are linked directly to the water supply network. Direct piped connection is the minimum acceptable water supply service standard (Ministry of Urban Development, n.d.). If the coverage fraction is low, water resilience intensity is also low as the water supply service's stress amplifies. More than one-third of the city area accounts for low water coverage ranging between 40 and $60 \%$ prone to low water resilience (34.41\%) (Fig. 5).

\section{Per capita water supply (PWS)}

The sufficiency of the municipal water supply system to source enough raw water, process it to potable standards, and feed it into the distribution system is denoted by per capita water supply. This represents the overall adequacy of water supplied to meet the population's needs in each ward (Ministry of Urban Development, n.d.). More than one-fifth of the city receives water less than 40 lpcd (23.80\%), accounting for very low water resilience (Table 3). About half of the city gets water between 40 and 90 lpcd (48.19\%), falling under low water resilience (Fig. 5).

\section{Distance from waterbodies and wetlands (DSW)}

As per the Ministry of environment and forests' regulations, $500 \mathrm{~m}$ distance from water bodies and wetlands is considered the sensitive zone. About one-third of the total area $(33.23 \%)$ is observed to fall under this sensitive zone (Fig. 5), nearly half and one-fifth of the total area $(48.88 \%, 17.90 \%)$ considered as the "moderate", and "high" subjected to water resilience, respectively (Table 3 ).

\section{Population density (PD)}

This denotes the number of inhabitants per sq. $\mathrm{km}$. Droughts and floods have a more significant impact if population density is higher (Kablan et al. 2017). This is because it increases water stress and is susceptible to damages during flood/storm surges. More than onefourth of the study area has a population density ranging between 20,000 and 50,000 persons $/ \mathrm{km}^{2}$ (30.09\%), accounting for low water resilience (Fig. 5).

\section{Slope (SP)}

The slope in Chennai city ranges from 0 to $95 \%$. It is observed that about three-fourth of the study area (73.41\%) falls in the range of 0 to 5 per cent slope (Fig. 6). The majority of the city area under this category are 


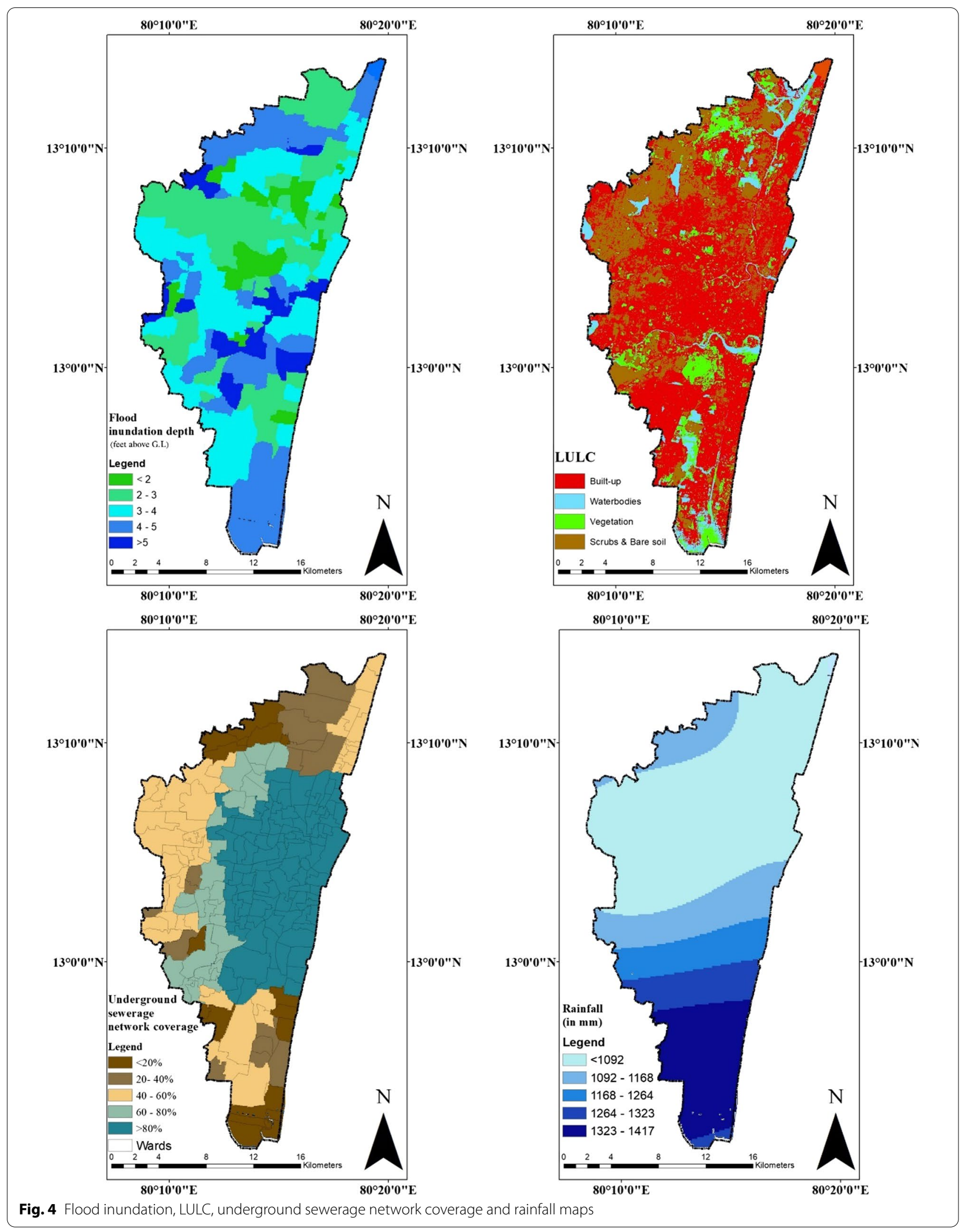




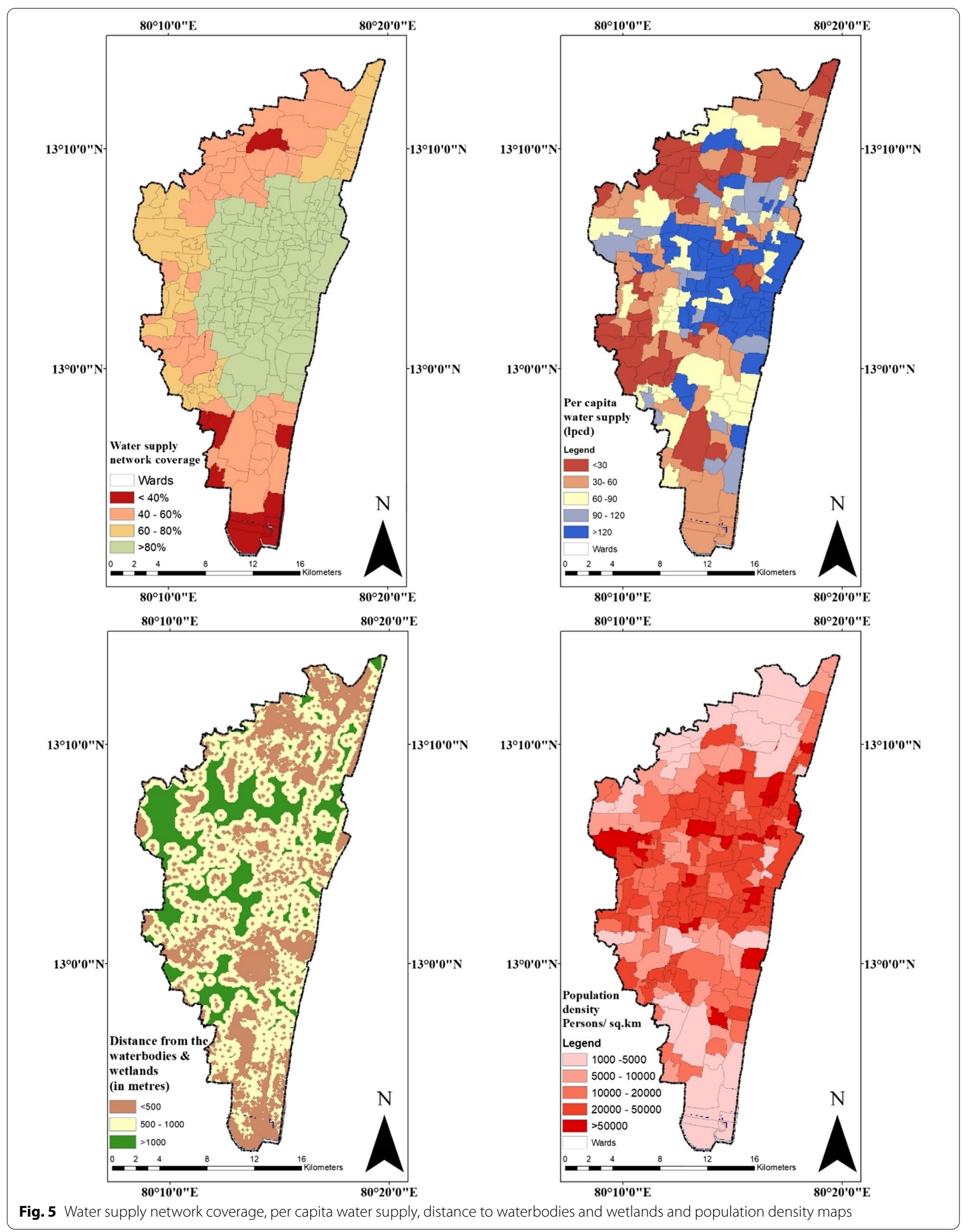




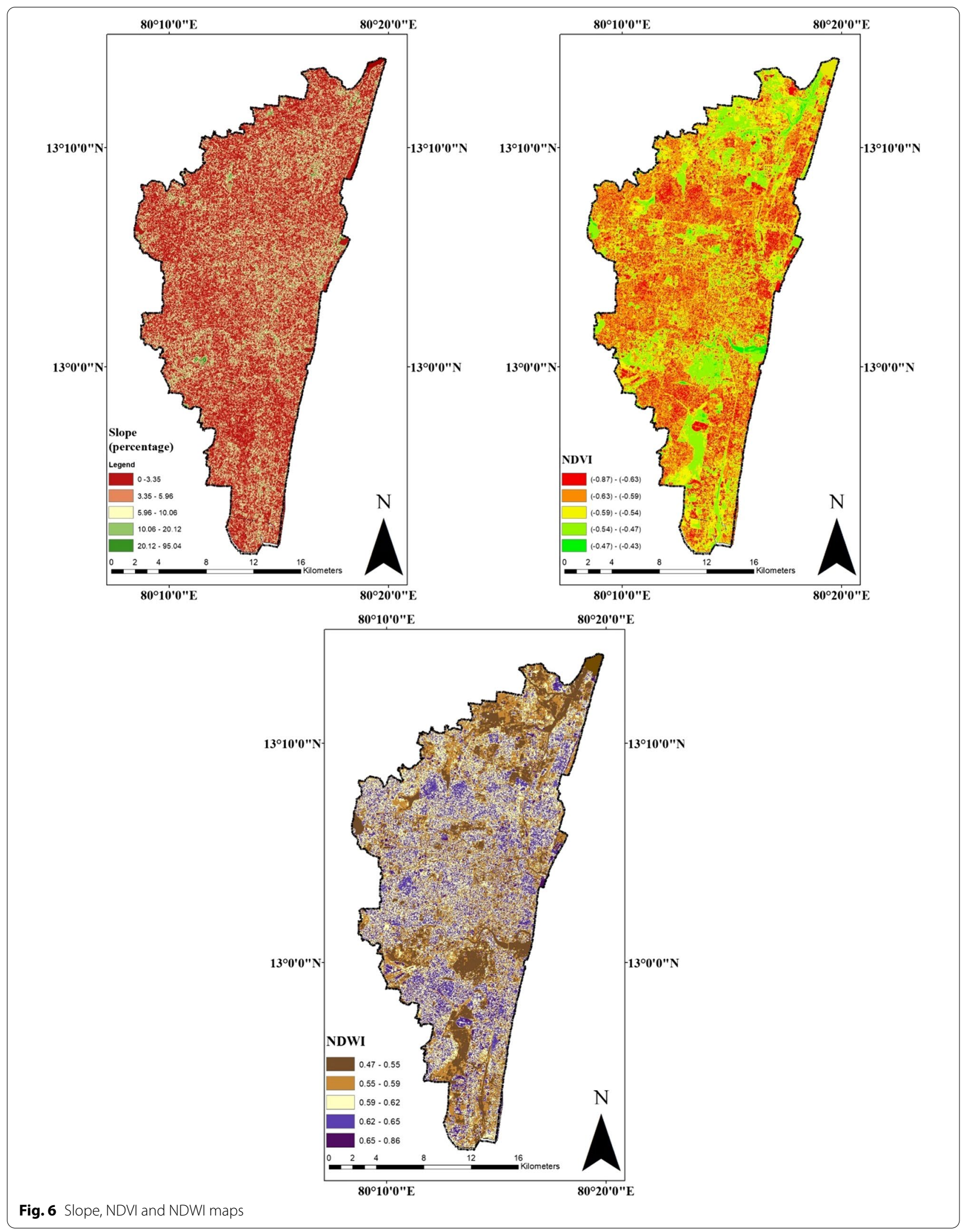


affected by floods and have very low water resilience intensity (Table 3).

\section{Normalized difference vegetation Index (NDVI)}

The normalized difference vegetation index (NDVI) shows vegetation cover. Bare areas having negative values are prone to flood and poor groundwater potential. Vegetation increases infiltration capacity. Positive values in NDVI show shrubs, forest cover. Most of the area of Chennai city includes settlements; hence the values of NDVI are negative. It has been observed that more than half of the study area (56\%) have very low negative values subjected to very low water resilience (Fig. 6).

\section{Normalized difference water index (NDWI)}

Normalized difference water index (NDWI) predicts soil and wetness depth. Areas with very low and low NDWI values denote the bare soil category. It totally accounts for two-fifth of the study area (40.43\%), subject to very low and low water resilience (Fig. 6). The relatively higher water index area with sparse canopy cover account for one-fourth of the study area (25\%).

\section{Water resilience mapping}

Water resilience mapping is a multifaceted process, including the factors related to drought, flood and water infrastructure systems in Chennai city. Integration of GIS, remote sensing and AHP-based weighted overlay technique with fifteen potential factors helps to determine diverse levels of water resilience zones in the study area. In this method, the thematic layers of these resilience factors were combined. This study focuses on preparing a water resilience mapping of Chennai city and determining each factor's significance in delineating the water resilience zone.

Assessing the criticality/significance of a component over the other is the prime focus of multi-criteria analysis based AHP. A pairwise comparison decision matrix is computed to determine the thematic layers' weights using the AHP method (Saaty 1980) (Table 2). The pairwise distinction, normalized weight calculation, and consistency ratio were computed as explained in the methodology to evolve a reasonable inference. The CR ratio is calculated as follows $C R=[((16.18-15) /$ $(15-1)) / 1.59$ ]; here the principal eigenvector $\left(\lambda_{\max }\right)$ is calculated as 16.18, number of parameters $=15$; According to (Saaty 1980) for 15 parameters, random consistency index is 1.59. As a result, the CR value of 0.052 is less than 0.1 , which clearly shows that the judgement made in the pairwise comparison is consistent and acceptable. The normalized weights of each factor derived from the AHP method show the intensity of these factors' influence on water resilience. The normalized weights evolved are: soil depth (0.167), geomorphology (0.149), drainage density (0.125), depth to water table (0.108), flood inundation depth (0.094), land use/land cover (0.073), underground sewerage network coverage (0.068), water supply network coverage (0.055), rainfall (0.042), per capita water supply (0.034), distance from the water bodies (0.025), population density (0.021), slope (0.015), normalized difference in vegetation index $(0.012)$, normalized difference in water index (0.010). The thematic layers of the above parameters were assigned suitable weights and varying scores to each subclass of the parameter. The subclasses were scored between ( 1 and 9 ) based on expert opinions, local knowledge based on experience and published literature. The scoring value increases with an increase in water resilience capability (Table 3 ). The lower the score, the lower is the water resilience. This emphasises that the strength to retaliate and recover from water-related disturbances is also low. Once the weights are specified to each factor and scores to each subclass, the water resilience zones can be determined by overlapping all the thematic layers using weighted overlay analysis. Before overlapping, all the thematic layer's resolutions are resampled to $30 \mathrm{~m}$ resolution using ArcGIS. Furthermore, the zones are classified into five levels of water resilience, viz, 'very low', 'low', 'moderate,' 'high' and 'very high' (Fig. 7). $12.09 \%$ and $23.67 \%$ of the city area is subjected to very low $\left(51.48 \mathrm{~km}^{2}\right)$ and low water resilience $\left(100.85 \mathrm{~km}^{2}\right)$, respectively, susceptible to maximum damages during extremities. Areas subjected to 'moderate' and 'high' and 'very high' water resilience are $44.67 \%$ $\left(190.277 \mathrm{~km}^{2}\right), 19.43 \%\left(82.76 \mathrm{~km}^{2}\right)$ and $0.15 \%\left(0.623 \mathrm{~km}^{2}\right)$ of the study area, respectively.

The northern and southern parts of the city are subjected to very low and low water resilience, constituting more than one-third of the city area. They are susceptible to maximum damages during flood/storm surges and drought. Water resilience zone mapping helps in decision making for effective planning and management of the city. Integrated planning intervention is crucial in lowering these influencing factors' impact damages by the city's development planning authorities.

\section{Accuracy assessment and sensitivity analysis}

The water resilience mapping elucidates accuracy in delineating the susceptible areas to water-related risks through the AHP method. During the 2015 flood, heavy rainfall (October-November 2020) and water-scarce period (April-June 2019), 38 sites were recorded with their GPS coordinates through field visits and India Water Resource Information System. For validating the efficiency of the WRZ mapping, the area under curve (AUC) method was employed, comparing the groundwater levels, flood events and the final water resilience 


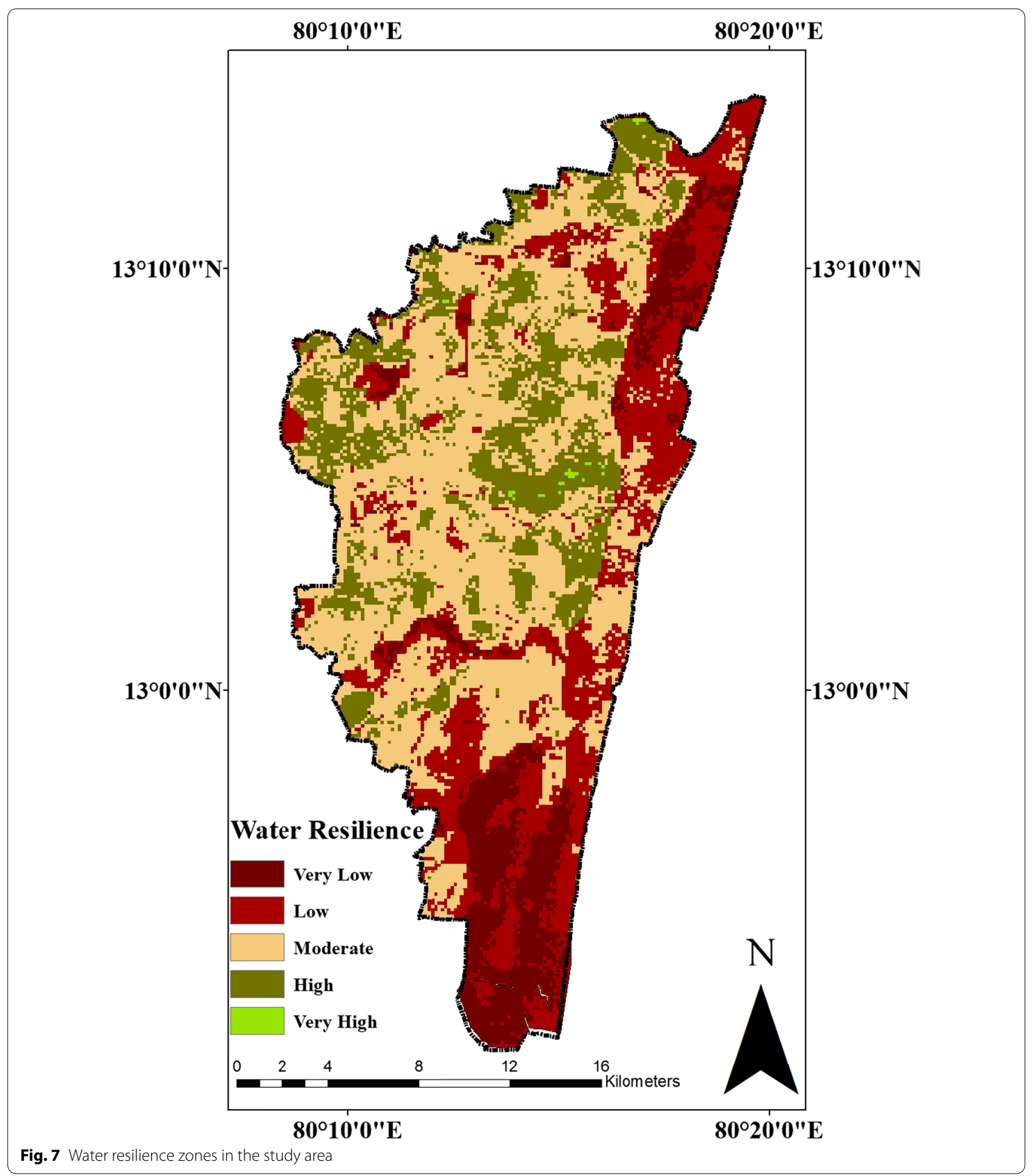

map. Various statistical evaluation measures such as the AUC curve, Freidman and Wilcoxon signed-rank tests are used to quantitatively validate the model (Khosravi et al. 2018; Pham et al. 2016). AUC is adopted in the present study as it is regarded as one of the most prominent approaches for determining the efficacy of the developed method (Hoque et al. 2020; Msabi and Makonyo 2021). The AUC was computed based on the cumulative percentage of the area under susceptibility, and the cumulative percentage of the testing data sets, 
Table 4 Changes in water resilience zone when parameters are removed

\begin{tabular}{|c|c|c|c|c|c|c|c|}
\hline \multirow[t]{2}{*}{ S. No. } & \multirow[t]{2}{*}{ Parameters removed } & \multicolumn{5}{|c|}{ Water resilience level } & \multirow[t]{2}{*}{ Average (\%) } \\
\hline & & Very low (\%) & Low (\%) & Moderate (\%) & High (\%) & Very high (\%) & \\
\hline 1 & Soil depth & -38.35 & -11.63 & -32.22 & +112.06 & +6.45 & 40.14 \\
\hline 2 & Geomorphology & -27 & +84 & -3 & -78 & -97 & 57.82 \\
\hline 3 & Drainage density & +59.85 & +2.91 & -0.99 & -38.23 & -35.48 & 27.49 \\
\hline 4 & Depth to groundwater table & +30.49 & -10.10 & -11.73 & +18.99 & +174.19 & 49.10 \\
\hline 5 & Flood inundation & +39.33 & -17.06 & +2.26 & -8.46 & -54.84 & 24.39 \\
\hline 6 & Land use/land cover & +2.85 & -14.65 & -0.93 & +17.83 & +51.61 & 17.57 \\
\hline 7 & Underground sewerage network coverage & +24.12 & +5.55 & +0.24 & -22.54 & +29.03 & 16.40 \\
\hline 8 & Water supply network coverage & +31.27 & +5.21 & +0.28 & -26.19 & -32.26 & 19.04 \\
\hline 9 & Rainfall & -3.64 & +3.91 & -12.77 & +25.41 & +190.32 & 47.21 \\
\hline 10 & Per capita water supply & +8.37 & -3.77 & -4.02 & +8.51 & +16.13 & 8.16 \\
\hline 11 & Distance to waterbodies & +4.18 & -3.81 & -3.51 & +9.90 & +29.03 & 10.09 \\
\hline 12 & Population density & +13.17 & -2.08 & -2.18 & -0.78 & +16.13 & 6.87 \\
\hline 13 & Slope & +4.81 & -5.43 & -6.66 & +18.75 & +25.81 & 12.29 \\
\hline 14 & NDVI & +2.50 & -1.58 & -1.18 & +3.04 & +6.45 & 2.95 \\
\hline 15 & NDWI & +3.56 & +0.18 & +0.71 & -4.01 & -6.45 & 2.98 \\
\hline
\end{tabular}

Here + denotes increase in the area; - denotes a decrease in the area

including the flood events and groundwater level. The AUC curve is plotted in Additional file 1: Figure S1. The AUC score is 0.8012 , or $80.12 \%$, indicating that the spatial mapping model used for water resilience has a high level of accuracy. The percentage variation in the area's change under different water resilience classes (very low, low, moderate, high and very high) when a parameter is removed from the assessment is detailed in Table 4.

- When the following parameters, geomorphology, depth to the groundwater table, rainfall, and soil depth are removed, it showed a maximum average deviation in the area by $57.82 \%, 49.10 \%, 47.21 \%$ and $40.14 \%$, respectively.

- The maximum average deviation in each of the cases mentioned above was compared with the original delineated water resilience areas in Fig. 8.

- When the parameters drainage density, flood inundation depth, water supply network coverage, LULC and underground sewerage network are excluded in the analysis, it showed deviation ranging between $27.49 \%$ and $16.40 \%$.

- The removal of the geomorphology parameter decreased the very low water resilience area by $27 \%$ (Fig. 8).

- When the depth to groundwater table is excluded, it increased the high-water resilience area by $174.19 \%$ (Fig. 8).
- It is observed that more area is included in the highwater resilience zone when the depth to groundwater table parameter is excluded from the study.

Sensitivity analysis clearly shows the parameter's controlling capacity in effectively delineating the water resilience zone. Table 4 clearly shows the vitality of every parameter employed in assessing the water resilience zones in Chennai city.

\section{Limitations}

The study's constraints and disadvantages stem from a lack of access to complete databases of specific parameters and the data quality. For instance, the sewer type and its existing condition cannot be included in the study due to a shortage of data and low-quality information. Incorporating these factors will aid in understanding the complete causal linkage between the variables influencing water resilience in the study area. Furthermore, the resolution of the raw data analysed lowered the analysis's quality. For example, the data for the underground sewer network coverage and water supply network coverage employed in the case study was only obtainable by ward level; the precise GPS coordinates are unavailable. Advancements in data collection technologies will undoubtedly continue to enhance data quality in the future, making the suggested model highly effective. Future studies might benefit from comparisons of other approaches, such as fuzzy AHP, ANP, and fuzzy ANP. 


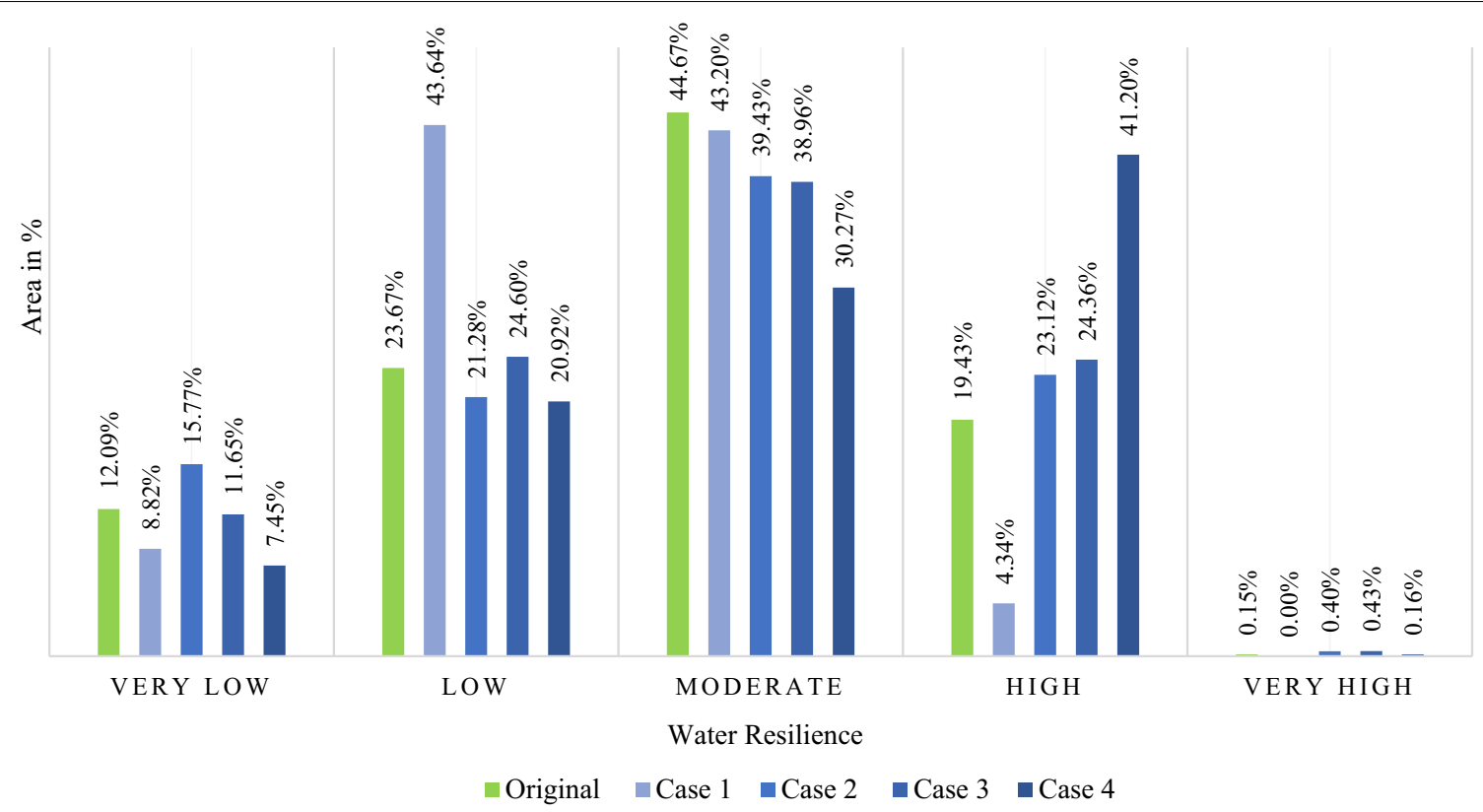

Fig. 8 Changes in the area by removing geomorphology, depth to the groundwater table, rainfall and soil depth. Case 1: Change in water resilience zone's area by removing geomorphology parameter. Case 2: Change in water resilience zone's area by removing depth to groundwater table parameter. Case 3: Change in water resilience zone's area by removing rainfall parameter. Case 4: Change in water resilience zone's area by removing soil depth parameter

\section{Conclusion}

In this study, Chennai's water resilience zones were effectively determined using the integration of GIS, remote sensing and AHP. The results delineated the study area in five different classes showing the level of water resilience: very low (12.09\%), low (23.67\%), moderate (44.67\%), high $(19.43 \%)$ and very high $(0.15 \%)$. The methodology chosen is focused on developing reliable water resilience zones that should be effectively used to mitigate and manage flood, drought, storm surges and any other water-related disturbances in an integrated manner, as it is the backbone of urban water resilience. Very low and low water resilience zones are primarily constituted in the southern and northern parts of the city. The area under curve plotting determines the accuracy of delineation of the water resilience zones, evaluated based on groundwater levels, and flood events at several areas on the final map. Sensitivity analysis examined the importance of all the parameters in determining the water resilience in Chennai city.

Our results are essential tools for researchers, urban planners, and development authorities to plan the city's development effectively. It becomes a tool for the urban indicators identifying where the system is vulnerable to potential water-related risks. Appropriate planning measures should be drafted to mitigate and plan for very low, low and moderate water resilience areas as they are more susceptible to water-related stress and disruptions.
According to the findings, this evaluation should be used in local analyses as the first step toward increasing resilience, defined by the remarkable ability to manage threats through innovative governance solutions and public participation. The use of the map is vital in ensuring the nature of intervention in the study area to reduce the system's susceptibility. The approach is logical and generic in the structure; it can be employed in other parts of India or elsewhere with or without necessary modifications.

The following are the plausible interventions, where resilience strategies can be imbibed: Priority in maintaining and preventing the deterioration of water bodies, wetlands, forest and tree cover areas. Strengthening water supply services, stormwater drain network, sewerage infrastructure, enhancing the capacity of desalination and sewage treatment plants, sewage water reuse and reducing groundwater depletion rate for effectively design towards optimal water resilience planning in the study area. The water resilience zone mapping determines the intensity at which the above measures can be implemented-for instance, the very low and low water resilience areas accounting for $152.33 \mathrm{~km}^{2}$ ought to be prioritized in area development plans for reducing water-related risks in the coming years. An integrated mechanism involving government departments, NGOs and local people is vital in this regard. Based on the proposed water resilience map, several 
bottom-up approaches such as robust decision making, scenario-neutral planning, and decision scaling can be developed. One significant aspect of these approaches is that the water resilience map serves as a baseline for planners to assess how alternative assumptions about future climate or other variables would impact decision-making. The AHP based water resilience planning methodology is evolved as a decision aid mechanism for employing resilience measures.

\begin{abstract}
Abbreviations
GIS: Geographic information system; MCDM: Multiple-criteria decisionmaking; DEM: Digital elevation model; MCDA: Multi-criteria decision analysis; AHP: Analytical hierarchy process; F-AHP: Fuzzy-analytical hierarchy process; LULC: Land use and land cover; NDVI: Normalized difference vegetation index; NDWI: Normalized difference water index; MCM: Million cubic metre; INR: Indian rupee; USD: United States Dollar; UNDP: United Nations Development Programme; LPCD: Litre per capita per day; CR: Consistency ratio; Cl: Consistency index; RI: Random index; SRTM: Shuttle radar topography mission; NIR: Near-infrared; SD: Soil depth; GM: Geomorphology; DD: Drain density; DW: Depth to the water table; FID: Flood inundation depth; RF: Rainfall; USN: Underground sewerage network; WSN: Water supply network; PWS: Per capita water supply; DSW: Distance from waterbodies and wetlands; PD: Population density; SP: Slope; WRZ: Water resilience zone; AUC: Area under curve; ANP: Analytical network process; NGO: Non-Governmental Organization.
\end{abstract}

\section{Supplementary Information}

The online version contains supplementary material available at https://doi. org/10.1186/s13717-021-00341-1.

Additional file 1: Fig. S1. Validation of the Water Resilience Model computed with AUC.

Additional file 2: Table S1. Profile of the Experts.

\section{Acknowledgements}

We want to thank the reviewers for their thoughtful comments towards improving the manuscript. The authors want to especially thank Dr Korlapati Satyagopal, IAS Dr E.Yuvaraj (RIMES), and all the associated officials in the Tamil Nadu State Disaster Management Authority, Chennai Metropolitan Water Supply and Sewerage Board, and the Chennai City Corporation departments for their valuable help in data collection.

\section{Authors' contributions}

RK: the first author is currently conducting her PhD research on planning for optimal water resilience in Chennai city. This work is part of the research in the completion of one of the objectives. She played a significant role in conceptualization, investigation, field-work, writing original drafts, editing, application of software techniques, interpretation and discussion of results. She is researching under the supervision of the second author. VD: supervision. Both the authors read and approved the final manuscript.

\section{Funding}

This research received no external funding.

\section{Availability of data and materials}

The data sets generated and/or analysed during the current study are available in the [India Water Resources Information System, Geological Survey of India, USGS Earth Explorer] repository, [https://indiawris.gov.in/wris/\#/, https:// bhukosh.gsi.gov.in/Bhukosh/Public, https://earthexplorer.usgs.gov/. And also, the data sets used and/or analysed during the current study are also available from the corresponding author on reasonable request.

\section{Declarations}

Ethics approval and consent to participate

Not applicable.

\section{Consent for publication}

Not applicable.

\section{Competing interests}

The authors declare that they have no competing interests.

Received: 2 June 2021 Accepted: 5 November 2021

Published online: 08 December 2021

\section{References}

Abebe Y, Kabir G, Tesfamariam S (2018) Assessing urban areas vulnerability to pluvial flooding using GIS applications and Bayesian Belief Network model. J Clean Prod 174:1629-1641. https://doi.org/10.1016/j.jclepro. 2017.11.066

Achu AL, Thomas J, Reghunath R (2020) Multi-criteria decision analysis for delineation of groundwater potential zones in a tropical river basin using remote sensing, GIS and analytical hierarchy process (AHP). Groundwater Sustain Dev 10:100365. https://doi.org/10.1016/j.gsd.2020.100365

Aykut T (2021) Determination of groundwater potential zones using Geographical Information Systems (GIS) and Analytic Hierarchy Process (AHP) between Edirne-Kalkansogut (northwestern Turkey). Groundwater Sustain Dev 12:100545. https://doi.org/10.1016/j.gsd.2021.100545

Aon Benfield (2015) Global Catastrophe Recap November 2015 Report (Issue November). http://thoughtleadership.aon.com/Documents/20151208-ifnovember-global-recap.pdf

Aon Benfield (2016) 2015 Annual Global Climate and Catastrophe Report. http://thoughtleadership.aon.com/Documents/20160113-ab-if-annualclimate-catastrophe-report.pdf

Basabe P (2013) Hyogo Framework for Action 2005-2015. In: Bobrowsky PT (ed) Encyclopedia of Natural Hazards. Encyclopedia of Earth Sciences Series. Springer, Dordrecht. https://doi.org/10.1007/978-1-4020-4399-4_ 180

Bocchini P, Frangopol D, Ummenhofer T, Zinke T (2014) Resilience and sustainability of civil infrastructure: toward a unified approach. J Infrastruct Syst 20:4014004. https://doi.org/10.1061/(ASCE)IS.1943-555X.0000177

Boyaj A, Ashok K, Ghosh S, Devanand A (2018) The Chennai extreme rainfall event in 2015: the Bay of Bengal connection. Clim Dyn 50(7):2867-2879. https://doi.org/10.1007/s00382-017-3778-7

Bremner L (2020) Planning the 2015 Chennai floods. Environ Plan E Nat Space 3(3):732-760. https://doi.org/10.1177/2514848619880130

CMWSSB (n.d.) Lake Storage Levels, Chennai Metropolitan Water Supply and Sewerage Board. Retrieved September 18, 2021, from http://123.63.203. 150/public/lake.htm

Corporation GC (2021) Missing Links Storm Water Drainage Project for the Core City Areas of Greater Chennai Corporation Environmental Impact Assessment Report (Issue January 2021)

Cutter SL, Burton CG, Emrich CT (2010) Disaster resilience indicators for benchmarking baseline conditions. J Homeland Secur Emerg Manage 7(1). https://doi.org/10.2202/1547-7355.1732

Desalegn H, Mulu A (2021) Flood vulnerability assessment using GIS at Fetam watershed, upper Abbay basin, Ethiopia. Heliyon 7(1):e05865. https://doi. org/10.1016/j.heliyon.2020.e05865

Ekmekcioğlu Ö, Koc K, Özger M (2021) District based flood risk assessment in Istanbul using fuzzy analytical hierarchy process. Stoch Env Res Risk Assess 35(3):617-637. https://doi.org/10.1007/s00477-020-01924-8

Ekmekcioğlu Ö, Koc K, Özger M (2021b) Stakeholder perceptions in flood risk assessment: a hybrid fuzzy AHP-TOPSIS approach for Istanbul, Turkey. Int J Disaster Risk Reduction 60:102327. https://doi.org/10.1016/j.ijdrr.2021. 102327

Gogate NG, Kalbar PP, Raval PM (2017) Assessment of stormwater management options in urban contexts using multiple attribute 
decision-making. J Clean Prod 142:2046-2059. https://doi.org/10.1016/j. jclepro.2016.11.079

Government of Tamil Nadu (2017) Report of the Comptroller and Auditor General of India on Performance Audit of Flood Management and Response in Chennai and its Suburban Areas. http://www.indiaenvironmentportal. org.in/files/file/Performance_Audit_of_Flood_Management_and_Respo nse in Chennai_and its Suburban_Area.pdf

Hasan A, Elmualim A, Rameezdeen R, Baroudi B, Marshall A (2018) An exploratory study on the impact of mobile ICT on productivity in construction projects. Built Environ Project Asset Manage 8(3):320-332. https://doi. org/10.1108/BEPAM-10-2017-0080

Holling CS (1973) Resilience and stability of ecological systems. Annu Rev Ecol Syst 4:1-23. https://doi.org/10.1146/annurev.es.04.110173.000245

Hoque MAA, Pradhan B, Ahmed N (2020) Assessing drought vulnerability using geospatial techniques in northwestern part of Bangladesh. Sci Total Environ 705:135957. https://doi.org/10.1016/j.scitotenv.2019.135957

Jain P, Ramsankaran RAAJ (2019) GIS-based integrated multi-criteria modelling framework for watershed prioritisation in India- a demonstration in Marol watershed. J Hydrol 578:124131. https://doi.org/10.1016/j.jhydrol. 2019.124131

Kablan MKA, Dongo K, Coulibaly M (2017) Assessment of social vulnerability to flood in urban Côte d'Ivoire using the MOVE framework. Water 9(4):292. https://doi.org/10.3390/w9040292

Kazakis N, Kougias I, Patsialis T (2015) Assessment of flood hazard areas at a regional scale using an index-based approach and analytical hierarchy process: application in Rhodope-Evros region, Greece. Sci Total Environ 538:555-563. https://doi.org/10.1016/j.scitotenv.2015.08.055

Khosravi K, Pham BT, Chapi K, Shirzadi A, Shahabi H, Revhaug I, Prakash I, Tien Bui D (2018) A comparative assessment of decision trees algorithms for flash flood susceptibility modeling at Haraz watershed, northern Iran. Sci Total Environ 627:744-755. https://doi.org/10.1016/.scitotenv.2018.01. 266

Kourgialas NN, Karatzas GP (2011) Gestion des inondations et méthode de modélisation sous SIG pour évaluer les zones d'aléa inondation-une étude de cas. Hydrol Sci J 56(2):212-225. https://doi.org/10.1080/02626 667.2011 .555836

Kourgialas NN, Anyfanti I, Karatzas GP, Dokou Z (2018) An integrated method for assessing drought prone areas - water efficiency practices for a climate resilient Mediterranean agriculture. Sci Total Environ 625:12901300. https://doi.org/10.1016/j.scitotenv.2018.01.051

Kumar PKD, Gopinath G, Seralathan P (2007) Application of remote sensing and GIS for the demarcation of groundwater potential zones of a river basin in Kerala, southwest coast of India. Int J Remote Sens 28(24):55835601. https://doi.org/10.1080/01431160601086050

Mahmoud SH, Gan TY (2018) Multi-criteria approach to develop flood susceptibility maps in arid regions of Middle East. J Clean Prod 196:216-229. https://doi.org/10.1016/j.jclepro.2018.06.047

Marlow DR, Moglia M, Cook S, Beale DJ (2013) Towards sustainable urban water management: a critical reassessment. Water Res 47(20):7150-7161. https://doi.org/10.1016/j.watres.2013.07.046

Massam BH (1988) Multi-criteria decision making (MCDM) techniques in planning. Progr Plan 30:1-84. https://doi.org/10.1016/0305-9006(88)90012-8

Miller JD, Hutchins M (2017) The impacts of urbanisation and climate change on urban flooding and urban water quality: a review of the evidence concerning the United Kingdom. J Hydrol Reg Stud 12:345-362. https:// doi.org/10.1016/j.ejrh.2017.06.006

Ministry of Urban Development, G. of I. (n.d.). Liveability standards in cities. https://smartnet.niua.org/sites/default/files/resources/LiveabilityStan dards.pdf

Mishra AK, Singh VP (2009) Analysis of drought severity-area-frequency curves using a general circulation model and scenario uncertainty. J Geophys Res Atmos 114:D06120. https://doi.org/10.1029/2008JD010986

Mosadeghi R, Warnken J, Tomlinson R, Mirfenderesk H (2015) Comparison of Fuzzy-AHP and AHP in a spatial multi-criteria decision making model for urban land-use planning. Comput Environ Urban Syst 49:54-65. https:// doi.org/10.1016/i.compenvurbsys.2014.10.001

Msabi MM, Makonyo M (2021) Flood susceptibility mapping using GIS and multi-criteria decision analysis: a case of Dodoma region, central Tanzania. Remote Sens Appl Soc Environ 21:100445. https://doi.org/10.1016/j. rsase.2020.100445
Mujumdar M, Bhaskar P, Ramarao MVS, Uppara U, Goswami M, Borgaonkar H, Chakraborty S, Ram S, Mishra V, Rajeevan M, Niyogi D (2020) Droughts and floods. In: Krishnan R, Sanjay J, Gnanaseelan C, Mujumdar M, Kulkarni A, Chakraborty S (eds) Assessment of Climate Change over the Indian Region. Springer, Singapore, pp 117-141. https://doi.org/10.1007/ 978-981-15-4327-2_6

Mukherjee I, Singh UK (2020) Delineation of groundwater potential zones in a drought-prone semi-arid region of east India using GIS and analytical hierarchical process techniques. Catena 194:104681. https://doi.org/10. 1016/j.catena.2020.104681

Narasimhan B, Bhallamudi M, Mondal A, Ghosh S, Mujumdar P (2016) Chennai Floods 2015: A Rapid Assessment Report. http://www.icwar.iisc.ac.in/wpcontent/uploads/2016/06/Chennai-Floods-Rapid-Assessment-Report.pdf

Ouyang NL, Lu SL, Wu BF, Zhu JJ, Wang H (2011) Wetland restoration suitability evaluation at the watershed scale - a case study in upstream of the Yongdinghe River. Procedia Environ Sci 10(Part C):1926-1932. https://doi. org/10.1016/j.proenv.2011.09.302

Paul M, Negahban-Azar M, Shirmohammadi A, Montas H (2020) Assessment of agricultural land suitability for irrigation with reclaimed water using geospatial multi-criteria decision analysis. Agric Water Manag 231:105987. https://doi.org/10.1016/j.agwat.2019.105987

Periyasamy P, Yagoub MM, Sudalaimuthu M (2018) Flood vulnerable zones in the rural blocks of Thiruvallur district, South India. Geoenviron Disasters 5:21. https://doi.org/10.1186/s40677-018-0113-5

Pham BT, Pradhan B, Tien Bui D, Prakash I, Dholakia MB (2016) A comparative study of different machine learning methods for landslide susceptibility assessment: a case study of Uttarakhand area (India). Environ Model Softw 84:240-250. https://doi.org/10.1016/j.envsoft.2016.07.005

Pohekar SD, Ramachandran M (2004) Application of multi-criteria decision making to sustainable energy planning - a review. Renew Sust Energ Rev 8(4):365-381. https://doi.org/10.1016/..rser.2003.12.007

Rajaveni SP, Nair IS, Elango L (2016) Evaluation of impact of climate change on seawater intrusion in a coastal aquifer by finite element modelling. J Clim Change 2:111-118. https://doi.org/10.3233/JCC-160022

Roumeau S, Seifelislam A, Jameson S, Kennedy L, Roumeau S, Seifelislam A, Jameson S, Kennedy L, Governance W, Kennedy L (2015) Water governance and climate change issues in Chennai. pp 1-34

Ruet J, Gambiez M, Lacour E (2007) Private appropriation of resource: impact of peri-urban farmers selling water to Chennai Metropolitan Water Board. Cities 24(2):110-121. https://doi.org/10.1016/j.cities.2006.10.001

Saaty TL (1980) The analytic hierarchy process: planning, priority setting, resource allocation. McGraw-Hill International Book Co.

Saaty TL (2006) There is no mathematical validity for using fuzzy number crunching in the analytic hierarchy process. J Syst Sci Syst Eng 15(4):457-464

Saaty TL, Tran LT (2007) On the invalidity of fuzzifying numerical judgments in the Analytic Hierarchy Process. Math Comput Model 46(7-8):962-975. https://doi.org/10.1016/j.mcm.2007.03.022

Saaty TL (2008) Relative measurement and its generalization in decision making: why pairwise comparisons are central in mathematics for the measurement of intangible factors: the Analytic Hierarchy/Network Process. Rev Real Acad Cienc Exactas Fis Nat Ser A-Mat 102(2):251-318.

Sarmah T, Das S, Narendr A, Aithal BH (2020) Assessing human vulnerability to urban flood hazard using the analytic hierarchy process and geographic information system. Int J Disaster Risk Reduct 50:101659. https://doi.org/ 10.1016/j.jidr.2020.101659

Saunders W, Becker J (2015) A discussion of resilience and sustainability: land use planning recovery from the Canterbury earthquake sequence, New Zealand. Int J Disaster Risk Reduct 14:73-81. https://doi.org/10.1016/j. ijdrr.2015.01.013

Sirdaş S, Sen Z (2009) Spatio-temporal drought analysis in the Trakya region, Turkey. Hydrol Sci J 48(5):809-820. https://doi.org/10.1623/hysj.48.5.809. 51458

Sivakumar VL, Radha Krishnappa R, Nallanathel M (2020) Drought vulnerability assessment and mapping using multi-criteria decision making (MCDM) and application of analytic hierarchy process (AHP) for Namakkal District, Tamilnadu, India. Mater Today Proc 43:1592-1599. https://doi.org/10. 1016/j.matpr.2020.09.657

Srivastava PK, Bhattacharya AK (2006) Groundwater assessment through an integrated approach using remote sensing, GIS and resistivity techniques: 
a case study from a hard rock terrain. Int J Remote Sens 27(20):45994620. https://doi.org/10.1080/01431160600554983

Sudha Rani NNV, Satyanarayana ANV, Bhaskaran PK (2015) Coastal vulnerability assessment studies over India: a review. Nat Hazards 77(1):405-428. https://doi.org/10.1007/s11069-015-1597-x

UNDP (1987) Hydrogeological and artificial recharge studies, Madras, India: technical report. UN, Department of Technical Co-operation for Development, New York

Walker B, Salt D (2012) Resilience practice: building capacity to absorb disturbance and maintain function. Island Press, Washington, DC. https://doi. org/10.5822/978-1-61091-231-0

Wilson JP, Mitasova H, Wright DJ (2000) Water resource applications of geographic information systems. URISA J 12(2):61-79
World Resources Institute (2015) Aqueduct Water Risk Atlas. https://www.wri. org/data/aqueduct-global-maps-21-data

Zabihi H, Alizadeh M, Wolf ID, Karami M, Ahmad A, Salamian H (2020) A GISbased fuzzy-analytic hierarchy process (F-AHP) for ecotourism suitability decision making: a case study of Babol in Iran. Tourism Manage Perspect 36:100726. https://doi.org/10.1016/j.tmp.2020.100726

\section{Publisher's Note}

Springer Nature remains neutral with regard to jurisdictional claims in published maps and institutional affiliations.

\section{Submit your manuscript to a SpringerOpen ${ }^{\odot}$ journal and benefit from:}

- Convenient online submission

- Rigorous peer review

- Open access: articles freely available online

- High visibility within the field

- Retaining the copyright to your article

Submit your next manuscript at $\boldsymbol{\nabla}$ springeropen.com 